\title{
Do coastal fronts influence bioerosion patterns along Patagonia? Late Quaternary ichnological tools from Golfo San Jorge
}

Article in Journal of Marine Systems · July 2017

DOI: 10.1016/j.jmarsys.2017.07.010

CITATIONS

0

5 authors, including:
READS

83

\section{Sebastián Richiano}

National Scientific and Technical Research C... 46 PUBLICATIONS 246 CITATIONS SEE PROFILE

\section{Marina Laura Aguirre}

National Scientific and Technical Research C... 52 PUBLICATIONS 842 CITATIONS

SEE PROFILE

Some of the authors of this publication are also working on these related projects:

Project
Colaboración Centro de Investigaciones Geológicas, UNLP-CONICET, La Plata (Argentina) y la Universidad Pablo de Olavide, Sevilla (España) View project

Argentina View project 


\title{
Do coastal fronts influence bioerosion patterns along Patagonia? Late Quaternary ichnological tools from Golfo San Jorge
}

\author{
Sebastián Richiano $^{\mathrm{a}, *}$, Marina Aguirre ${ }^{\mathrm{b}, \mathrm{c}}$, Ignacio Castellanos ${ }^{\mathrm{b}}$, Karen Davies ${ }^{\mathrm{b}}$, Ester Farinati ${ }^{\mathrm{d}}$ \\ a Instituto Patagónico de Geología y Paleontología (CONICET-CENPAT), Boulevard Brown 2915, Puerto Madryn, Chubut, Argentina \\ b Facultad de Ciencias Naturales y Museo, Universidad Nacional de La Plata, Edificio Institutos, Laboratorios y Cátedras, calle $64 N^{\circ} 3,1900$ La Plata, Argentina \\ c CONICET, Cátedra de Biogeografía (FCNYM-UNLP), Argentina \\ ' Departamento de Geología, Universidad Nacional del Sur, San Juan 670, Bahía Blanca, Argentina
}

\section{A R T I C L E I N F O}

\section{Keywords:}

Ichnology-Gastropods-Bivalves-Bryozoans

activity-Pleistocene-Holocene

\begin{abstract}
A B S T R A C T
Late Quaternary marine molluscan skeletal concentrations from Argentina constitute a remarkable record of variations in palaeoceanographical conditions during interglacial times (mainly ca. $125 \mathrm{ka}$ to present). Particularly, the Golfo San Jorge coastal area represents an extraordinary geographical zone to target from different points of view, mainly due to its linkage between northern and southern Patagonia, characterized by particular and contrasting physico-chemical conditions with direct consequences for littoral marine communities, determining their composition and structure. Among varied biological activities controlled by different environmental factors (i.e., substrate nature, sedimentation rates, water depth, sea surface temperature, salinity, nutrients-productivity), bioerosion traces can provide palaeoenvironmental evidence with important implications for palaeoclimate interpretations. In addition, the application of bioerosion patterns regionally and through time is a recent valuable worthy palaeoenvironmental tool not as yet developed for Patagonia. We attempted to characterize, qualitatively/semiquantitatively, the ichnotaxonomic composition of the coastal area of northern Golfo San Jorge since the Late Pleistocene; to compare results with those obtained for other geographical areas along Patagonia and the Bonaerensian coastal sectors; lastly, to evaluate its palaeoenvironmental/palaeoclimatic significance in a clue area in terms of circulation patterns near the Southern Ocean climatic pump. At Bustamante (Northern Patagonia Frontal System) Domichnia traces were dominant during the Late Pleistocene while Praedichnia in the mid-Holocene. Bustamante exhibits the highest ichnodiversity for the whole Argentinean coastal area. Ichnodiversity is not strongly different between Late Pleistocene and mid-Holocene interglacials and compared to present; however, the relative abundance of some ichnotaxa (e.g., Oichnus, Iramena, Pennatichnus, at Camarones; Oichnus, Iramena, Pinaceocladichnus, at Bustamante) differs across time. These variations, particularly the highest abundance in the Late Pleistocene (mainly Last Interglacial) of traces made by bryozoans- associated at present with modern enhanced productivity levels and coastal fronts in the Argentine continental shelf- point to higher productivity and more intensified northern Patagonia Front, as a result of a different palaeocirculation pattern, reinforcing previous independent sources of evidence based on molluscan palaeobiogeographical analyses.
\end{abstract}

\section{Introduction}

Bioerosion in marine environments, worldwide and through geological time, represents a remarkable evidence of varied biological activities controlled by different environmental factors (i.e., substrate nature, sedimentation rates, water depth, sea surface temperature and salinity, nutrients-productivity; interspecific interactions) (e.g., Taylor and Wilson, 2003; Bromley, 2004; Goldring et al., 2007; Seilacher, 2007; Buatois and Mangano, 2011; Santos et al., 2012; Allmonn and Martin, 2014; Richiano et al., 2015; Liow et al., 2016). Moreover, bioerosion traces can provide palaeoenvironmental evidence with important implications for palaeoecological (e.g. Bromley, 1994; Wilson, 2007) and palaeoclimate (e.g. Edinger, 2002; Edinger and Risk, 2007) interpretations. Also, the application of bioerosion studies as tools to provide information of ecological, evolutionary and environmental patterns - locally, regionally and through time- and of sea-level dynamics is an approach with growing scientific interest (Noble et al., 1995; Wilson et al., 1998; Uchman et al., 2002; Walker, 2007; Wisshak et al., 2011, Richiano et al., 2015; Huntley and Scarponi, 2015; among others). In the coastal area of Argentina in the Southwestern Atlantic

\footnotetext{
* Corresponding author.

E-mail addresses: richiano@cenpat-conicet.gob.ar (S. Richiano), maguirre@fcnym.unlp.edu.ar (M. Aguirre), farinati@uns.edu.ar (E. Farinati).
} 
bioerosion studies are still in its inception.

Late Quaternary marine skeletal concentrations from Argentina are rich in molluscs which exhibit a great variety of bioerosion structures (Farinati et al., 2006; Farinati, 2007; Richiano et al., 2012, 2015). Particularly, the Golfo San Jorge coastal area in Chubut province represents a geographically target zone, the linkage between northern and southern Patagonia, where the confluence of different physicochemical conditions occur (Roux et al., 1993; Fernández et al., 2003, 2005, 2007, 2008; Acha et al., 2004; Carreto et al., 2007; Rivas and Pisoni, 2010; Olguín-Salinas et al., 2015; Ruiz-Etcheverry et al., 2016; Pierini et al., 2016) with direct consequences for the littoral marine communities, determining their composition and structure (Roux et al., 1993; Glembocki et al., 2015). Most of the work carried out in this region corresponds to modern and fossil marine Quaternary biotas, mainly focused on molluscs, phytoplankton and fisheries (Bastida et al., 1981, 1992, 2007; Acha et al., 2004; Bogazzi et al., 2005; Fernández et al., 2007; Aguirre et al., 2011a) but scarce research is available dealing with ichnology (Richiano et al., 2012, 2015). Ichnology, and more specifically bioerosion, brings light into hidden biological contents, as organisms which are devoid of hard skeletons (e.g., porifers, annelids, bryozoans) can leave traces as a result of their life activities: borings, attachment, fixation, rowing, breakage, among others (Ziegler, 1983).

In contrast to previous studies aiming to characterize bioerosion structures (and their trace makers) for a single taxon (e.g., Richiano et al., 2015) in order to reduce the possible variables (taxonomic, ecological and environmental controls) for ichnodiversity, in this paper we search for general patterns of bioerosion recorded on all available shells collected along the area of study (different molluscan taxa).

On the other hand, independent sources of evidence pointed to a different (warmer SST) mid-Holocene scenery (Aguirre et al., 2011a; Rohling, 2013; Yin and Berger, 2015; Spratt and Lisiecki, 2016) in contrast with the present and with a colder Late Pleistocene setting (Aguirre et al., 2013; but see Bauch, 2013). Bioerosion patterns from central Patagonia could add in assessing palaeoclimate trends during the last interglacials evidenced in the area.

The aim of this study is firstly, to characterize the ichnotaxonomic composition recorded in molluscan shells (Gastropods and Bivalves) along the coastal area of northern Golfo San Jorge since the Late Pleistocene; secondly, compare the results with those obtained for other geographical areas along Patagonia and northwards in the Bonaerensian coastal sector (Argentina); thirdly, to evaluate the palaeoenvironmental/palaeoclimate significance of the bioerosion patterns recognized. This information is relevant given that this is a clue area in terms of circulation patterns and physical/biotic parameters (Suppl. App. 1) and, especially, due to the air-sea $\mathrm{CO}_{2}$ flux, linked to productivity (high rates of photosynthetic carbon fixation) (e.g., Gruber, 2015) and with implications for the thermohaline dynamics (Berger et al., 2010).

\section{Background information}

The marine Late Quaternary molluscan-rich concentrations preserved in Patagonia occur almost continuously along $>1000 \mathrm{~km}$ in Río Negro, Chubut and Santa Cruz provinces (Fig. 1). They integrate beach ridges, marine terraces and estuarine deposits, Mid-Late Pleistocene to Holocene in age. They extend from the modern supratidal zone to a few kilometers inland, reaching generally ca. $5-10 \mathrm{~km}$.

\subsection{Geographical and geological setting}

Along most of the Argentinean coastal area, molluscan shell concentrations are abundant, exceptionally well preserved, and reflect past littoral environments during high sea-level episodes. In Patagonia, they were originated during the last transgressive-regressive marine cycles (Marine Isotope Stages, MIS) (Haq et al., 1987; Zachos et al., 2001;
Lisiecki and Raymo, 2005): MIS11, 9, 7, 5 (Mid-Late Pleistocene) and MIS1 (Holocene) (Schellmann and Radtke, 2010), of which the most continuous and richest fossiliferous deposits are MIS1, 5 and 7. Previous studies in Patagonia provided complete source of information for morphostratigraphy, sedimentology, geochronological, taphonomical and palaeoecological aspects of these deposits (e.g., Feruglio, 1950; Cionchi, 1988; Codignotto et al., 1988, 1992; Schellmann, 2007; Schellmann and Radtke, 2010; Aguirre et al., 2005, 2006, 2007, 2008, 2009, 2011a, 2011b, 2013, 2015; Ribolini et al., 2011; Richiano et al., 2012, 2015).

Feruglio (1950) defined for Patagonia the classical framework of six systems of "Marine Terraces", which integrate beach ridges, marine terraces and estuarine deposits. The Patagonian Pleistocene terraces which contain abundant molluscan shells, widely spread and better preserved, are MTIV and V. They represent at least three Pleistocene high sea-level episodes, partially assignable to MIS5 (ca. $125 \mathrm{ka}$ ), 7 (ca. $225 \mathrm{ka}$ ), 9 (ca. $325 \mathrm{ka}$ ) and are at different heights, roughly between 10 and $>50 \mathrm{~m}$ above present m.s.l. The Patagonian Pleistocene Terrace MTIII was considered with doubts either as an older Pleistocene episode or pre-Pleistocene in age, whereas modern dating pointed to MIS11 (ca. $400 \mathrm{ka}$ ) or Mid-Pliocene (Schellmann and Radtke, 2010; Dutton et al., 2015), which still needs to be tested. The MTVI represents the most external deposits and corresponds to the last transgressive high sealevel episode occurred during the mid-Holocene (ca. 7.5-4.5 ka; MIS1) (Codignotto et al., 1988; Rutter et al., 1989, 1990; Schellmann, 2007; Schellmann and Radtke, 2010 and references therein).

In Chubut province they correlate with MIS11, 9, 7, 5 and MIS1. Particularly, the best preserved deposits are located along southern Chubut at Bahía Vera-Bahía Camarones and Bahía Bustamante areas (Fig. 1). The Mid-Holocene landforms, at ca. 5-12 m above present m.s.l., provided the richest molluscan assemblages. The Holocene molluscan fauna as a whole is more diverse, better preserved and exhibit abundant and varied bioerosion structures (Aguirre et al., 2011a; Richiano et al., 2012) (Suppl. App. 2).

In general, the marine terraces from Patagonia show a central part which is mainly composed of massive, clast-supported conglomerate, with a scarce sandy matrix interpreted as the core terrace (Fig. 2A). Above the massive core, well stratified sediments (fine conglomerates with abundant sandy matrix) are apparent, representing the foreshore and shoreface deposits (Fig. 2B-E). These sediments commonly show low angle planar cross stratification and trough cross stratification. All the shells analysed in this study come from the upper part $(5-30 \mathrm{~cm}$ deep) of the terraces, where the shells are more abundant and better preserved (Richiano et al., 2012, 2015). The modern samples come from adjacent littoral areas at the same latitude of the fossiliferous coastal landforms (Fig. 2F).

\subsection{Palaeontological background}

The molluscan concentrations contain a majority of parautochthonous assemblages (sensu Kidwell et al., 1986) made mainly of gastropod and bivalve shells. A Summary list of the molluscan composition of the coastal deposits studied is provided in Table 1 (see also Suppl. App. 3).

Along Bahía Vera-Camarones area, the marine terraces contain gastropods and bivalves associated with occasional crustaceans, cnidarians, bryozoans, terebratulid brachiopods, and polychaete remains. Molluscs represent $91 \%$ of the total fauna in the assemblages from the adjacent modern nearshore (Aguirre et al., 2006). In all, 41 taxa belonging to 25 genera were identified with gastropods (24 species) outnumbering bivalves (17 species). The most characteristic taxa recorded are the gastropods: Nacella deaurata, N. magellanica, Fissurella spp., Crepidula protea, C. dilatata, Natica isabelleana, Buccinanops spp. and Trophon spp., and the bivalves Brachidontes purpuratus, Protothaca antiqua, Clausinella gayi, Mactra cf. patagonica and Ostrea tehuelcha. In the modern littoral the most typical taxa are Aulacomya atra, Clausinella 


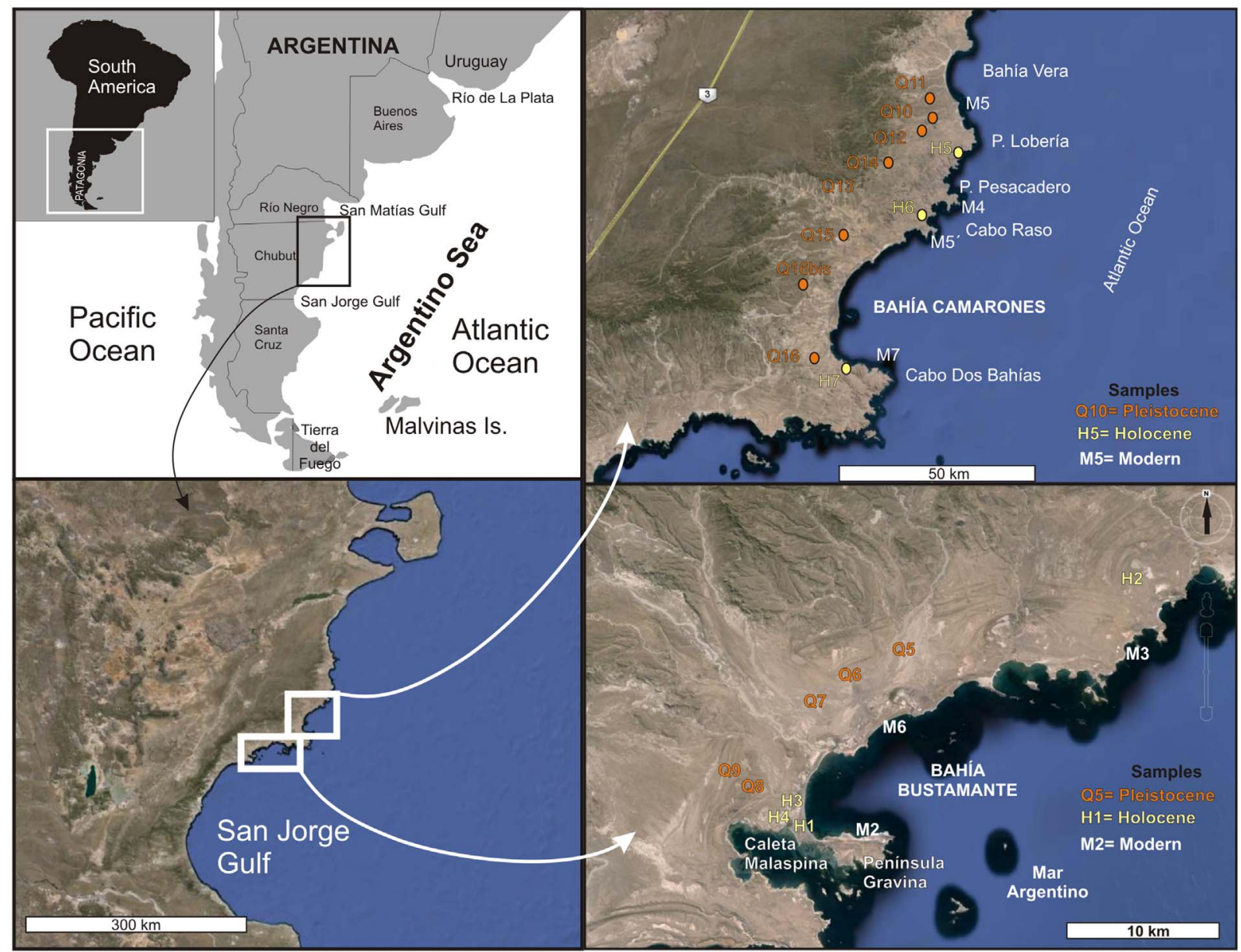

Fig. 1. Location of the study area and sampled localities from the coastal area of northern Golfo San Jorge, Argentina, (Southwestern Atlantic, SWA).
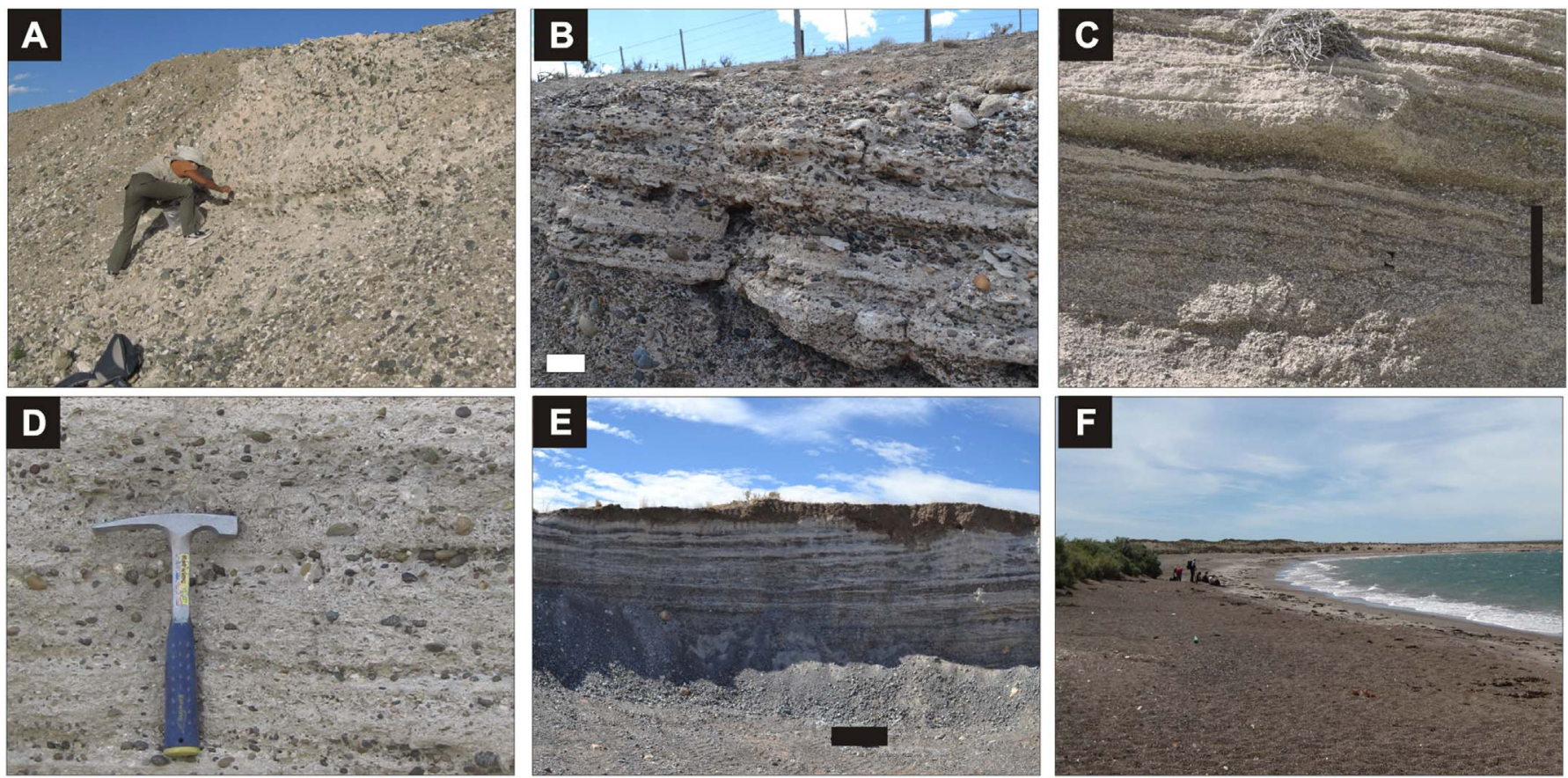

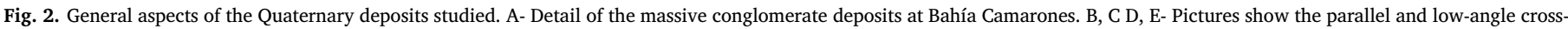
stratification of the beach ridge deposits. F- Modern beach near Bahía Bustamante area. For picture B scale bar $10 \mathrm{~cm}$; pictures C and E $1 \mathrm{~m}$. 
Table 1

Diversity, distribution and ecological information of the molluscan taxa recovered from the Camarones and Bustamante areas (for complete details see Aguirre et al., 2005, 2006). STRAT: stratigraphical range. For complete information about authors of species (see Suppl. App. 3).

\begin{tabular}{|c|c|c|c|c|c|c|c|c|c|c|c|c|c|c|c|c|c|}
\hline \multirow{3}{*}{ Distribution and ecological data } & \multicolumn{7}{|c|}{ Range } & \multirow{2}{*}{\multicolumn{3}{|c|}{ Bathymetry }} & \multirow{2}{*}{\multicolumn{2}{|c|}{ Substrate }} & \multirow{2}{*}{\multicolumn{5}{|c|}{ Life mode }} \\
\hline & \multicolumn{2}{|c|}{ Strat. } & \multicolumn{5}{|c|}{ Modern geographic } & & & & & & & & & & \\
\hline & $M$ & \begin{tabular}{|l|l|} 
PL & HOL \\
\end{tabular} & PAND & ANT & BRAZ & ARG & MAG & Sup. & Int. & Sub. & So & $\mathrm{H}$ & $\mathrm{F}$ & $\mathrm{S}$ & Carn. & Herb & Filtr \\
\hline \multicolumn{18}{|l|}{ Gatropods } \\
\hline \multicolumn{18}{|l|}{ Patinigera deaurata } \\
\hline \multicolumn{18}{|l|}{ Nacella (P.) delicatissima } \\
\hline \multicolumn{18}{|l|}{ Nacella (P.)magellanica } \\
\hline Diodora patagonica & $?$ & & & & & & & & & & & & & & & & \\
\hline \multicolumn{18}{|l|}{ Fissurella oriens } \\
\hline \multicolumn{18}{|l|}{ Fissurtella picta } \\
\hline \multicolumn{18}{|l|}{ Fissurella radiosa } \\
\hline \multicolumn{18}{|l|}{ Tegula patagonica } \\
\hline Tegula (C.) atra & & & & & & & & & & & & & & & & & \\
\hline Ataxocerithium pullum & & & & & & & & & & & & & & & & & \\
\hline Crepidula aculeata & & & & & & & & & & & & & & & & & \\
\hline Crepidula protea & & & & & & & & & & & & & & & & & \\
\hline Crepidula onyx & & & & & & & & & & & & & & & & & \\
\hline Crepidula cf. unguiformis & & & & & & & & & & & & & & & & & \\
\hline Crepidula dilatata & & & & & & & & & & & & & & & & & \\
\hline Trochita pileus & & & & & & & & & & & & & & & & & \\
\hline Trophon varians & & & & & & & & & & & & & & & & & \\
\hline Trophon geversianus & & & & & & & & & & & & & & & & & \\
\hline Natica isabelleana & & & & & & & & & & & & & & & & & \\
\hline Epitonium sp. & & & & & & & & & & & & & & & & & \\
\hline Acanthina monodon & & & & & & & & & & & & & & & & & \\
\hline Pareuthria plumbea & & & & & & & & & & & & & & & & & \\
\hline Buccinanops globulosus & & & & & & & & & & & & & & & & & \\
\hline Buccinanops paytensis & & & & & & & & & & & & & & & & & \\
\hline Odontoc.magellanica & & & & & & & & & & & & & & & & & \\
\hline Siphonaria lessoni & & & & & & & & & & & & & & & & & \\
\hline Bivalves & & & & & & & & & & & & & & & & & \\
\hline Mytilus (M.) edulis & & & & & & & & & & & & & & & & & \\
\hline Brachidontes (B.) purpuratus & & & & & & & & & & & & & & & & & \\
\hline Brachidontes cf. purpuratus & & & & & & & & & & & & & & & & & \\
\hline Brachidontes (B.) rodriguezi & & & & & & & & & & & & & & & & & \\
\hline Aulacomya atra & & & & & & & & & & & & & & & & & \\
\hline Ostrea tehuelcha & & & & & & & & & & & & & & & & & \\
\hline Ostrea $s p$ & & & & & & & & & & & & & & & & & \\
\hline Aequipecten tehuelchus & & & & & & & & & & & & & & & & & \\
\hline Zygochlamys patagonicus & & & & & & & & & & & & & & & & & \\
\hline Pectinidae indet. & & & & & & & & & & & & & & & & & \\
\hline Mactra cf. patagonica & & & & & & & & & & & & & & & & & \\
\hline Pitar rostratus & & & & & & & & & & & & & & & & & \\
\hline Eurhomalea exalbida & & & & & & & & & & & & & & & & & \\
\hline Protothaca antiqua & & & & & & & & & & & & & & & & & \\
\hline Clausinella gayi & & & & & & & & & & & & & & & & & \\
\hline Venericardia procera & & & & & & & & & & & & & & & & & \\
\hline Veneridae indet. & & & & & & & & & & & & & & & & & \\
\hline Panopea abbreviata & & & & & & & & & & & & & & & & & \\
\hline Lyonsia sp. & & & & & & & & & & & & & & & & & \\
\hline
\end{tabular}

gayi, Aequipecten tehuelchus and Protothaca antiqua (bivalves), and Crepidula spp., Trophon geversianus and Nacella spp. (gastropods) (Table 1, Suppl. App. 3).

Along Bustamante area the macroinvertebrate faunal composition consists of a majority of molluscan shells and associated barnacles, bryozoans, brachiopods, polychaetes as epizoic encrustations, and the accompanying microfauna (ostracods and forams). A total of 30 characteristic molluscan taxa were discriminated from these deposits: 16 gastropods and 11 bivalves (Aguirre et al., 2005). Gastropods outnumber bivalves in most fossil samples. The main species identified are: Fissurella oriens, F. radiosa, Nacella magallanica, N. deaurata, Tegula patagonica, T. atra, Crepidula protea, C. cf. unguiformis, Trophon varians, T. geversianus, Odontocymbiola magallanica, Ataxocerithium pullum; Epitonium magellanicum, Buccinanops globulosus, B. paytensis, Siphonaria lessoni. The characteristic bivalve species are Mytilus edulis chilensis, Aulacomya atra, Brachidontes purpuratus, B. rodriguezi, Aequipecten tehuelchus, Ostrea sp., Protothaca antiqua, Clausinella gayi, Venericardia procera, Pitar rostratus, the most typical in all the ridge systems are: $P$.antiqua and B. purpuratus. In the modern adjacent nearshore the most typical taxa identified are the gastropods $C$. dilatata, $N$. deaurata, T.geversianus, T. patagonica, B. globulosum and the bivalves B. purpuratus, Aulacomya atra (Table 1, Suppl. App. 3).

Regarding ecological requirements of modern representatives for each species, data on distribution, life mode and habitat are summarized on Table 1. All the taxa are benthic, inhabitants of euhaline water masses in different oceans, mostly along the South Atlantic Ocean. The majority of these species live in the intertidal and/or upper infralittoral zones, although the most abundant ones are found in the supralittoral 
and intertidal. As a whole they are indicative of high energy conditions and hard substrates (coarse sand and pebbles or rocky bottoms).

Most of the molluscan assemblages represent taphocoenosis and constitute parautochthonous shell concentrations according to palaeoecological criteria (Kidwell et al., 1986; Fürsich and Flessa, 1987), where extensive biostratinomic and diagenetic bias of the shells can be excluded (Aberhan and Fürsich, 1991). According to our previous palaeoecological studies in many areas of the whole Argentine coast, the original molluscan communities lived in varied substrates of nearshore waters within the supralitoral, intertidal and upper infralittoral zones, mainly from 3 to $30 \mathrm{~m}$ deep. Due to their young age, high preservation grade and similarity (taxonomic fidelity) of the Late Pleistocene and Holocene molluscan assemblages regarding the present-day nearshore associations, they are ideal for palaeoenvironmental-analyses. On top of that, because they are time-averaged, these assemblages can record long-term conditions of the littoral environments (Aberhan and Fürsich, 1991; Flessa and Kowalewski, 1994; Meldahl, 2001; Kidwell, 2001).

\section{Material and methods}

The samples collected in the field belong to Late Pleistocene (mostly Last Interglacial, MIS5), fossil Holocene (mostly mid-Holocene) and modern coastal landforms. The number, age and geographical position of the fossiliferous localities considered along the Bahía Camarones and Bahía Bustamante localities (Figs. 1, 2), respond to their largest extension in the field, better preservation degree as well as to their higher abundance of molluscan assemblages. In this sense, a total of 27 samples have been analysed for this study, 15 from Bahía Camarones area (4 modern, 3 middle Holocene, 8 Pleistocene) and 12 from Bahía Bustamante (3 modern, 4 middle Holocene, 5 Pleistocene) (Tables 2-4). Fossils were taken from exposures of natural cuttings, abandoned quarries, and well-preserved outcrops. It is important to highlight that the samples analysed in this study were previously used for palaeoecological and palaeobiogeographical studies (Aguirre et al., 2005, 2006, 2011a, 2015). In any case, for all the places sample volumes of $5000 \mathrm{~cm} 3$ (sediment and biogenic content) were taken from the fossiliferous levels. At modern sites, collection was made of all the material within a $1 \times 1 \mathrm{~m}$ surface in supratidal and intertidal zones. For the interpretation of malacological fossil assemblages whole shell specimens or fragments identifiable as one same individual shell were used for quantification (provided of whole aperture and at least part of the spire for gastropods; whole valves or fragments with preserved dentition and ligament for bivalves; complete - joint - bivalve shells are most unfrequent in these coastal deposits).

The material studied was washed by means of an ultrasonic cleaner (Lilis 3.8) and photographed using a digital camera (Nikon D3100) and a digital camera (Nikon Coolpix S10 VR) attached to a binocular loop (Nikon SMZ1000). The material examined for bioeosion traces was deposited at the División Geología of the Museo de La Plata (MLP-DCG) in Argentina: MLP-DCG-0007-1-226; 914-923) (details for collection numbers and species in Aguirre et al., 2005, 2006).
The ichnotaxonomic characterization was based on classifications available in the literature (Suppl. App. 2).

Qualitative/semiquantitative analyses of the dataset obtained followed our previous studies of gastropods and bivalves from the marine Late Quaternary of Argentina. We used qualitative data (presence/absence) for regional comparisons which represent the database available for the whole geographical area and time intervals considered (detailed quantitative data are available for some localities only). Estimations of ichnodiversity were conducted following previous published models (e.g., Wisshak et al., 2011; Richiano et al., 2015). For each time interval considered, the ichnodiversity was measured as a percentage of ichnotaxa preserved at each locality in relation to the total number of ichnotaxa recovered in the area of study ( $D=n i / n t \times 100$, where $n i$ is the number of ichnotaxa for each time at a particular locality, $n t$ is the total number of ichnotaxa along the whole area) (e.g., Margalef, 1982). The relative abundance of each ichnotaxon in the locality samples were analysed through pie graphs. We use bioerosion intensity in a nontraditional form; here it is defined as the percentage of shells with bioerosion relative to the total amount of bioclasts recovered.

To compare the ichnotaxonomic composition of the samples analysed, statistical significant differences between and within groups, arranged according to localities (Camarones, Bustamante), age (modern, Holocene, Late Pleistocene), taxa (gastropods, bivalves) and life habits and habitats (epifaunal, infaunal; supralittoral, intertidal, sublittoral), were analysed by means of a non parametric test (two-way analysis of similarity, ANOSIM; Bray-Curtis distance coefficient) and the software Past 2.03 (Hammer et al., 2001) which uses the crossed design (Clarke, 1993). As a post-hoc test pairwise ANOSIMs between all pairs of groups were obtained (significant comparisons at $p<0.05$ ).

The total ichnotaxa were plotted against the groups mentioned previously and a multivariate analysis (Cluster Analysis, CA) was applied to the matrix. The CA was performed using the software Past 2.03 (Hammer et al., 2001) and calculating a similarity matrix (SM) using Ward's method (Euclidean coefficient) to obtain a phenogram showing samples grouped according to their shared ichnotaxa.

\section{Results}

For the northern coastal area of Golfo San Jorge a total of 1396 shells of molluscs were analysed of which 884 are from Bahía Camarones and 512 from Bahía Bustamante (Table 2). On these shells 13 ichnogenera were identified: Caedichnus isp., Caulostrepsis isp., Centrichnus isp., Entobia isp., Finichnus isp., Iramena isp., Maeandropolydora isp., Oichnus isp., Pennatichnus isp., Pinaceocladichnus isp., Podichnus isp., Renichnus isp., Umbichnus isp. The most characteristic traces are shown in Fig. 3. The bioerosion activity recorded shows a fifty-fifty percentage (bioeroded vs. non bioeroded shells) for the whole area. Some compositional differences between Bahía Camarones and Bahía Bustamante coastal sectors are evident (see Table 2). No statistically significant differences exist between samples (Permutation N: 9999; Factor Cae, R: 0,13554, p(same): 0,2271; Factor C, R: 0,53805, p(same): 0,0329).

Table 2

Total amount of shells studied from the Camarones and Bustamante areas and through time (Late Pleistocene, mid-Holocene, recent $=$ Modern).

\begin{tabular}{|c|c|c|c|c|c|c|c|c|c|}
\hline & \multicolumn{3}{|c|}{ B. CAMARONES } & \multicolumn{3}{c|}{ B. BUSTAMANTE } & \multicolumn{3}{c|}{ N GOLFO SAN JORGE } \\
\cline { 2 - 10 } & $\begin{array}{c}\text { Shells with } \\
\text { bioerosion }\end{array}$ & $\begin{array}{c}\text { Shells } \\
\text { without } \\
\text { bioerosion }\end{array}$ & Total shells & $\begin{array}{c}\text { Shells with } \\
\text { bioerosion }\end{array}$ & $\begin{array}{c}\text { Shells } \\
\text { without } \\
\text { bioerosion }\end{array}$ & Total shells & $\begin{array}{c}\text { Shells with } \\
\text { bioerosion }\end{array}$ & $\begin{array}{c}\text { Shells } \\
\text { without } \\
\text { bioerosion }\end{array}$ & Total shells \\
\hline Pleistocene & 95 & 106 & 201 & 51 & 37 & 88 & 146 & 143 & 289 \\
\hline Holocene & 116 & 154 & 270 & 111 & 79 & 190 & 227 & 233 & 460 \\
\hline Modern & 185 & 228 & 413 & 138 & 96 & 234 & 323 & 324 & 647 \\
\hline Total & 396 & 488 & 884 & 300 & 212 & 512 & 696 & 700 & 1396 \\
\hline Total \% & 44.8 & 55.2 & 100 & 58.6 & 41.4 & 100 & 49.9 & 50.1 & 100 \\
\hline
\end{tabular}


Table 3

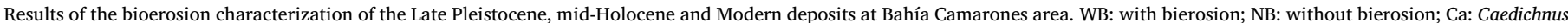

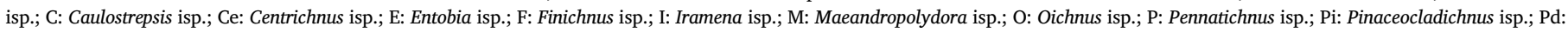
Podichnus isp.; R: Renichnus isp.; U: Umbichnus isp.

\begin{tabular}{|c|c|c|c|c|c|c|c|c|c|}
\hline \multirow{3}{*}{ Gastropoda } & \multicolumn{9}{|c|}{ Bahía Camarones } \\
\hline & \multicolumn{3}{|c|}{ Pleistocene } & \multicolumn{3}{|c|}{ Holocene } & \multicolumn{3}{|c|}{ Modern } \\
\hline & WB & NB & Ichnogenera & WB & NB & Ichnogenera & WB & NB & Ichnogenera \\
\hline \multicolumn{10}{|l|}{ Diodora patagonica } \\
\hline Fissurella oriens & & 1 & & & & & & & \\
\hline Fissurella radiosa & 2 & 2 & I & & & & 1 & 3 & $\mathrm{M}, \mathrm{I}$ \\
\hline Nacella delicatissima & & & & & & & 3 & 14 & $\mathrm{~F}, \mathrm{O}, \mathrm{I}$ \\
\hline Nacella magellanica & 1 & 1 & $\mathrm{I}$ & 2 & 19 & $\mathrm{I}$ & & 36 & \\
\hline Nacella deaurata & 5 & 13 & 0,1 & & & & & & \\
\hline Nacella sp. & & & & & & & 2 & 10 & $\mathrm{M}, \mathrm{I}$ \\
\hline Tegula patagonica & 1 & & I & & & & 11 & 13 & $\mathrm{M}, \mathrm{I}$ \\
\hline Tegula atra & 13 & 15 & $\mathrm{I}, \mathrm{C}, \mathrm{M}, \mathrm{O}$ & & & & & & \\
\hline Crepidula aculeata & 1 & & $\mathrm{M}$ & 2 & & I & 4 & & $\mathrm{M}, \mathrm{I}$ \\
\hline Crepidula protea & 3 & 1 & $\mathrm{M}, \mathrm{I}$ & 5 & 6 & $\mathrm{C}, \mathrm{M}$ & 10 & 19 & $\mathrm{M}, \mathrm{E}, \mathrm{C}$ \\
\hline Crepidula dilatata & 3 & & $\mathrm{I}, \mathrm{F}$ & 7 & 1 & $\mathrm{Pi}, \mathrm{I}, \mathrm{M}$ & 7 & & $\mathrm{M}, \mathrm{O}$ \\
\hline Crepidula cf. onyx & 3 & & $\mathrm{M}, \mathrm{I}, \mathrm{C}$ & & & & 20 & 8 & $\mathrm{C}, \mathrm{M}, \mathrm{Pi}, \mathrm{F}, \mathrm{O}, \mathrm{I}$ \\
\hline Crepidula sp. & & & & & & & 22 & 9 & $\mathrm{C}, \mathrm{M}, \mathrm{Pi}, \mathrm{F}, \mathrm{O}, \mathrm{I}$ \\
\hline Trophon varians & 11 & 4 & $\mathrm{M}, \mathrm{I}$ & 1 & 21 & $\mathrm{I}$ & 4 & 3 & $\mathrm{M}, \mathrm{O}$ \\
\hline Trophon geversianus & 4 & & $M$ & 19 & 4 & $\mathrm{I}, \mathrm{M}$ & 20 & 14 & $\mathrm{C}, \mathrm{M}, \mathrm{I}$ \\
\hline \multicolumn{10}{|l|}{ Trophon sp. } \\
\hline Odontocymbiola magellanica & 7 & 4 & $\mathrm{Pi}, \mathrm{I}, \mathrm{F}, \mathrm{P}, \mathrm{E}$ & 4 & 2 & $\mathrm{M}, \mathrm{I}, \mathrm{E}$ & 3 & 1 & I \\
\hline Buccinanops globulosus & 3 & 2 & $\mathrm{I}, \mathrm{M}, \mathrm{C}$ & & & & 6 & 1 & $\mathrm{I}, \mathrm{Pi}$ \\
\hline \multicolumn{10}{|l|}{ Buccinanops paytensis } \\
\hline Pareuthria plumbea & & 1 & & & 1 & & 2 & 3 & 1 \\
\hline Siphonaria lessoni & 1 & & 1 & & & & & 2 & \\
\hline Trochita pileus & & & & & & & 1 & 1 & $\mathrm{M}$ \\
\hline Volutidae indet & & & & 1 & 3 & $\mathrm{I}, \mathrm{Pi}$ & & & \\
\hline Total gas & 58 & 44 & & 41 & 57 & & 116 & 137 & \\
\hline BIVALVIA & WB & NB & Ichnogenera & WB & NB & Ichnogenera & WB & NB & Ichnogenera \\
\hline Mytilus edulis & 2 & & & 28 & 36 & $\mathrm{I}, \mathrm{O}, \mathrm{Pi}, \mathrm{M}, \mathrm{C}$ & & & \\
\hline Brachidontes purpuratus & 1 & 9 & $\mathrm{I}$ & 4 & 3 & $\mathrm{I}, \mathrm{O}$ & 2 & 7 & 0,1 \\
\hline Aulacomya atra & 1 & 2 & $\mathrm{Pi}$ & 2 & 3 & $\mathrm{M}, \mathrm{O}$ & 31 & 38 & $\mathrm{M}, \mathrm{I}$ \\
\hline Aequipecten tehuelchus & 1 & & $\mathrm{M}$ & & 1 & & 12 & 11 & $\mathrm{C}, \mathrm{M}, \mathrm{I}$ \\
\hline Protothaca antiqua & 5 & 33 & $\mathrm{~F}, \mathrm{I}$ & 2 & 5 & 0,1 & 4 & 8 & 0,1 \\
\hline Clausinella gayi & 7 & 3 & $\mathrm{I}, \mathrm{O}, \mathrm{Pi}$ & & & & 20 & 25 & $\mathrm{C}, \mathrm{M}, \mathrm{Pi}, \mathrm{O}, \mathrm{I}, \mathrm{Pd}$ \\
\hline Pitar rostratus & 4 & 3 & $\mathrm{I}, \mathrm{O}$ & & & & & & \\
\hline Lyonsia sp. & & & & & & & & 2 & \\
\hline Veneridae indet. & 16 & 12 & 1 & & & & & & \\
\hline Total Biv & 37 & 62 & 8 ichnotaxa & 75 & 97 & 6 ichnotaxa & 69 & 91 & 8 ichnotaxa \\
\hline Total & 95 & 106 & 201 SHELLS & 116 & 154 & 270 SHELLS & 185 & 228 & 413 SHELLS \\
\hline Total $\%$ & 47 & 53 & & 43 & 57 & & 45 & 55 & \\
\hline Ichnodiversity "D" \% & & & 61.5 & & & 46,15 & & & 61,5 \\
\hline
\end{tabular}

\subsection{Camarones area (Fig. 4A, B)}

At this locality a total of nine (9) ichnogenera were identified in 884 shells (453 Gastropods and 431 Bivalves; 396 with bioerosion, 44.8\%; 488 without bioerosion, 55.2\%). In order of importance they are: Iramena isp., Maeandropolydora isp., Oichnus isp., Entobia isp., Finichnus isp., Caulostrepsis isp., Pennatichnus isp., Pinaceocladichnus isp. and Podichnus isp. The results for each age considered are shown in Table 3 and Fig. 4C. Nevertheless, it is outstanding that the relative abundance of shells without bioerosion predominates in all ages through time, except for the Late Pleistocene gastropod shells. The ichnodiversity is equal for Pleistocene and Modern intervals ( 8 ichnogenera; $\mathrm{D}=61.5$ ) and minimum for fossil Holocene concentrations (6 ichnogenera, $\mathrm{D}=46.1$ ).

\subsection{Bustamante area (Fig. 5A, B)}

At this locality a total of twelve (12) ichnogenera were identified in 512 shells (215 Gastropods and 297 Bivalves; 300 with bioerosion, $58.6 \%$; 212 without bioerosion, 41.4\%). In order of importance they are: Iramena isp., Maeandropolydora isp., Oichnus isp., Pinaceocladichnus isp., Entobia isp., Finichnus isp., Caulostrepsis isp., Centrichnus isp., Renichnus isp., Umbichnus isp., Caedichnus isp. and Podichnus isp. The results for each age considered are shown in Table 4 and Fig. 5C. The bioerosion activity at this locality is higher than in the Camarones area, showing a total of $58.6 \%$ of shells with bioerosion. The average percentage of shells with bioerosion predominates in all ages and taxonomic groups, except for Holocene gastropods and Modern Bivalves. 
Table 4

Results of the bioerosion characterization of the Late Pleistocene, mid-Holocene and Modern deposits at Bahía Bustamante area. References as in Table 3.

\begin{tabular}{|c|c|c|c|c|c|c|c|c|c|}
\hline \multirow{3}{*}{ Gastropoda } & \multicolumn{9}{|c|}{ Bahía Bustamante } \\
\hline & \multicolumn{3}{|c|}{ Pleistocene } & \multicolumn{3}{|c|}{ Holocene } & \multicolumn{3}{|c|}{ Modern } \\
\hline & WB & NB & Ichnogenera & WB & NB & Ichnogenera & WB & NB & Ichnogenera \\
\hline Diodora patagonica & 3 & 1 & $\mathrm{C}, \mathrm{I}$ & & & & & & \\
\hline Nacella delicatissima & & & & & & & 1 & & $\mathrm{I}$ \\
\hline Nacella magellanica & & & & 1 & 2 & $\mathrm{Pd}$ & 1 & 8 & $\mathrm{R}$ \\
\hline Nacella deaurata & & & & 1 & & $\mathrm{Pd}$ & 13 & & $\mathrm{~F}, \mathrm{I}, \mathrm{Ce}, \mathrm{O}$ \\
\hline Tegula patagonica & 2 & 2 & $\mathrm{I}$ & & & & 4 & 5 & $\mathrm{M}, \mathrm{F}$ \\
\hline Tegula atra & 9 & 31 & $\mathrm{I}, \mathrm{C}, \mathrm{M}$ & & & & & & \\
\hline Crepidula aculeata & & & & 1 & & $\mathrm{O}$ & 3 & & $\mathrm{I}, \mathrm{M}, \mathrm{O}$ \\
\hline Crepidula protea & 11 & & $\mathrm{M}, \mathrm{O}, \mathrm{Pi}$ & 1 & 2 & $\mathrm{I}, \mathrm{O}$ & 12 & 2 & $\mathrm{O}, \mathrm{P}, \mathrm{C}$ \\
\hline Crepidula dilatata & 3 & & $\mathrm{I}, \mathrm{M}$ & 8 & 4 & $\mathrm{C}, \mathrm{I}, \mathrm{M}, \mathrm{F}, \mathrm{O}$ & 4 & 2 & $\mathrm{O}, \mathrm{I}, \mathrm{Ca}$ \\
\hline Crepidula sp. & & & & & & & 19 & 4 & $\mathrm{I}, \mathrm{M}, \mathrm{O}, \mathrm{F}$ \\
\hline Trophon varians & 3 & & $\mathrm{I}, \mathrm{M}, \mathrm{Ca}$ & & & & 7 & 2 & $\mathrm{I}, \mathrm{M}, \mathrm{Pi}$ \\
\hline Trophon geversianus & & & & & & & 9 & & $\mathrm{I}, \mathrm{F}, \mathrm{O}, \mathrm{M}, \mathrm{C}$ \\
\hline Trophon sp. & 2 & & $\mathrm{C}, \mathrm{I}$ & & & & & & \\
\hline Odontocymbiola magellanica & 2 & & I & 3 & 5 & $\mathrm{Ce}, \mathrm{Ca}, \mathrm{Pd}$ & 3 & & $\mathrm{E}, \mathrm{M}, \mathrm{Pi}$ \\
\hline Buccinanops globulosus & & & & & 1 & & 5 & 5 & $\mathrm{~F}, \mathrm{Pi}, \mathrm{I}$ \\
\hline Buccinanops paytensis & & & & & 2 & & 3 & & $\mathrm{Pi}, \mathrm{O}, \mathrm{C}$ \\
\hline Pareuthria plumbea & & & & 1 & 2 & $\mathrm{O}$ & & & \\
\hline Total gas & 35 & 34 & & 16 & 18 & & 84 & 28 & \\
\hline BIVALVIA & WB & NB & Ichnogenera & WB & NB & Ichnogenera & WB & NB & Ichnogenera \\
\hline Mytilus edulis & & & & 21 & 25 & $\mathrm{O}$ & 1 & & $\mathrm{O}$ \\
\hline Brachidontes purpuratus & & & & 37 & 24 & $\mathrm{O}$ & 8 & 9 & $\mathrm{O}$ \\
\hline Aulacomya atra & & & & & & & 9 & 9 & $\mathrm{M}, \mathrm{Pd}, \mathrm{I}, \mathrm{O}, \mathrm{C}$ \\
\hline Aequipecten tehuelchus & & & & & & & 5 & 40 & $\mathrm{C}, \mathrm{R}, \mathrm{Pd}$ \\
\hline Protothaca antiqua & 16 & 3 & $\mathrm{E}, \mathrm{I}, \mathrm{M}, \mathrm{Ce}, \mathrm{O}$ & 37 & 12 & $\mathrm{E}, \mathrm{I}, \mathrm{M}, \mathrm{Ce}, \mathrm{F}, \mathrm{O}$ & 31 & 10 & $\mathrm{I}, \mathrm{O}, \mathrm{E}, \mathrm{U}, \mathrm{F}, \mathrm{Pd}$ \\
\hline Total Biv & 16 & 3 & 8 ichnotaxa & 95 & 61 & 9 ichnotaxa & 54 & 68 & 13 ichnotaxa \\
\hline Total & 51 & 37 & 88 SHELLS & 111 & 79 & 190 SHELLS & 138 & 96 & 234 SHELLS \\
\hline Total $\%$ & 58 & 42 & & 58 & 42 & & 59 & 41 & \\
\hline Ichnodiversity "D" \% & & & 61.5 & & & 69.2 & & & 100 \\
\hline
\end{tabular}

The ichnodiversity shows an increased pattern from Pleistocene ( 8 ichnogenera, $\mathrm{D}=61.5$ ) to Modern (13 ichnogenera, $\mathrm{D}=100$ ) time intervals.

\subsection{Comparisons between and within localities}

Fig. 6 shows the relative abundance of bioerosion ichnotaxa from northern Golfo San Jorge at Camarones and Bustamante areas since the Late Pleistocene. The most common traces belong to Domichnia, Praedichnia and Fixichnia ethological categories (Supp. App. 2), but their relative abundance differ between localities and within localities according to the age of the deposits sampled.

At Camarones area, traces of Domichnia (borings produced during residence of the trace maker in the host) are dominant across time (Late Pleistocene, Holocene and Modern) (with a decreasing trend to present), followed by Praedichnia (drill holes, durophagous scars, bitings) and, less abundantly, by Fixichnia (superficial attachment scars) (Fig. 6). Iramena, followed by Oichnus and Maeandropolydora are constant and most abundant. The relative abundance of Iramena and Oichnus differs temporally: Iramena decreases since the Late Pleistocene to present and, inversely, Oichnus increases.

At Bustamante area, Domichnia traces are most abundant during the Late Pleistocene and Modern time intervals - but remarkably lower during the Holocene. Within the fossil Holocene deposits, Praedichnia is predominant while Fixichnia increases since the Late Pleistocene to present. Oichnus, Iramena, Entobia and Maeandropolydora are constant and most abundant (Fig. 6). Iramena predominates in the Late Pleistocene and Modern. Oichnus shows its maximum in the Holocene and minimum in the Late Pleistocene; Pennatichnus is absent in the Holocene.

Fig. 7 shows the results of applying cluster analysis to the presenceabsence matrix of ichnotaxa vs. locality samples. This diagram - complementary of Fig. 6 depicts similarity relationships among samples based on their ichnotaxa, allowing to discriminate between two main groups based on the shared traces preserved in gastropod and bivalve species. Group A (mostly from Bustamante area) includes two subgroups: A1, samples with traces on infaunal bivalves of all ages; A2, mainly Holocene and Pleistocene samples with traces on varied bivalves together with Holocene samples with traces on infralittoral gastropods. On the other hand, Group B (mostly from Camarones area) includes three subgroups: B1, mostly Camarones samples of all ages with traces on varied gastropods; B2, Camarones and Bustamante samples (Late Pleistocene and Modern) with traces on gastropods and bivalves of different habitats, with subgroup B2.1 (mostly Camarones samples with traces exclusively on gastropods) and B2.2 (mostly Camarones samples on gastropod and bivalves of shallower habitats). Also, a two-way cluster analysis on the same matrix comfirmed that Group A can be explained mainly by traces of Oichnus (Praedichnia) and Group B by Iramena and Maeandopolydora (Domichnia) (Fig. 7).

\section{Discussion}

The ichnotaxonomic characterization of northern Golfo San Jorge coastal area during the Late Quaternary (Tables 3, 4; Figs. 6, 7) shows that Bustamante and Camarones sectors are not remarkably dissimilar. However, rough differences are apparent (Figs. 3-7) and seem to represent responses to environmental controls on the trace makers responsable for bioeroded gastropod and bivalve shells since the Late Pleistocene (mainly Last Interglacial, MIS5).

In general terms, the taxonomic groups and the ecological requirements of the species exhibiting bioerosion traces (life habits and habitats shown in Table 1) do not seem to control the ichnological pattern geographically or across time (Figs. 6, 7), except for infaunal bivalve species of Group A (mostly Bustamante area, characterized by Oichnus, and secondarily by Caulostrepsis and Maeandropolydora) (Fig. 7), showing a mixture between live and postmortem bioerosive activities. In the remaining samples, however, species with different ecological requirements can exhibit the same ichnotaxa (Fig. 7).

Regarding a possible taphonomic bias, it is outstanding that only a very small number of our shells exhibit bioerosion structures on the 


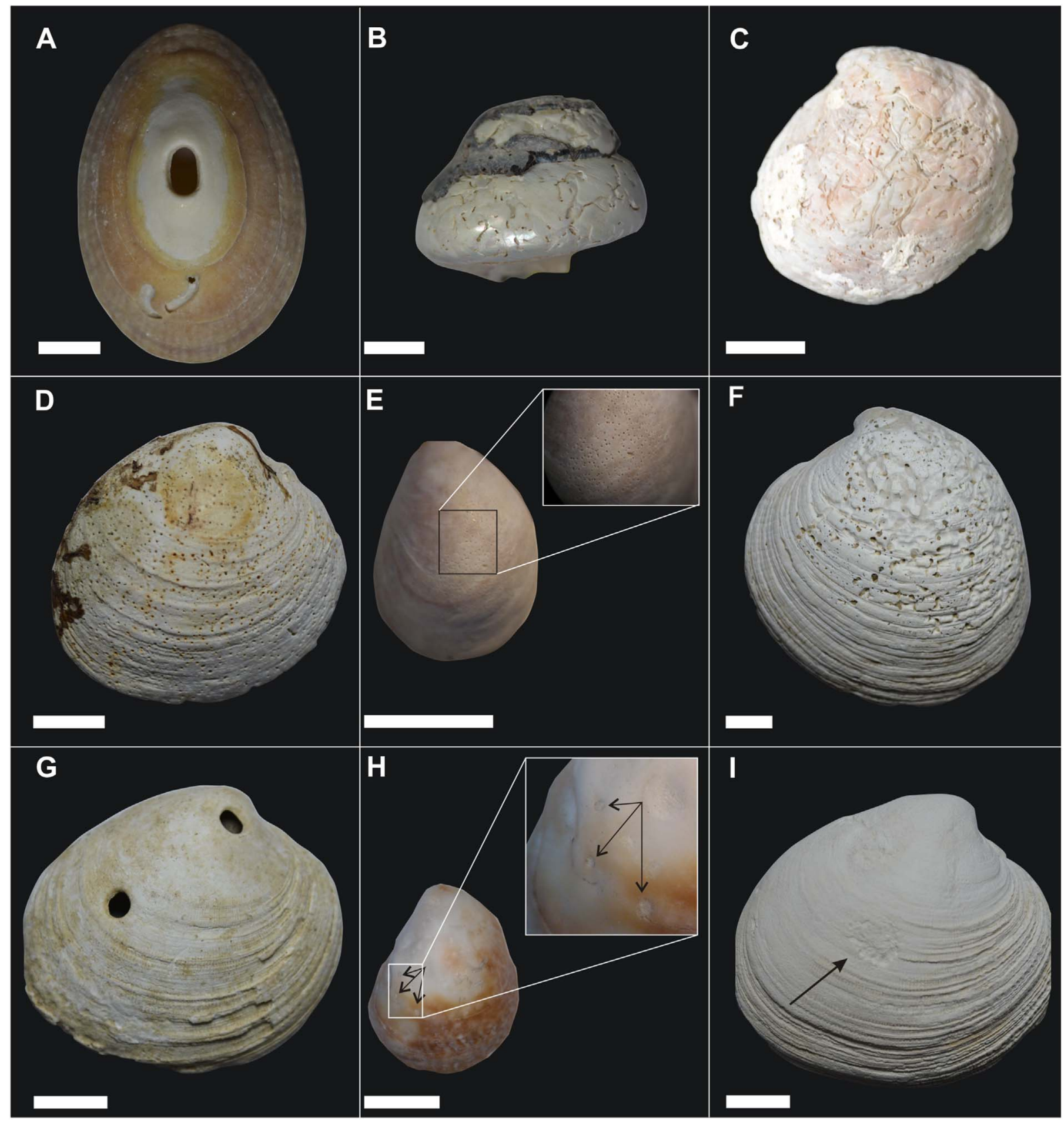

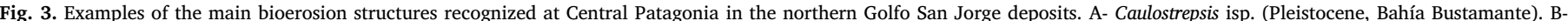

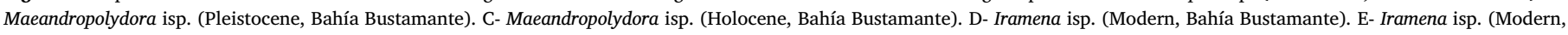

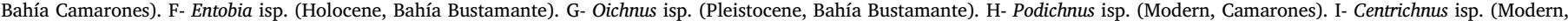
Bahía Bustamante). Scale bar: $1 \mathrm{~cm}$.

internal shell surface. This aspect has two implications: palaeoecological and taphonomical/palaeoenvironmental. Firstly, that the majority of the traces may be made during the life of the host and are linked to environmental conditions of their habitat; and secondly, when the traces were produced after death, the position of the shells occurred in hydrodynamic equilibrium (with the external surface upwards) pointing to reduced post-mortem transport, therefore also representative of the original littoral conditions.

In order to define environmental factors that could have influenced the bioerosive activity of the trace makers, a summary of the modern oceanographic parameters of the Mar Argentino (Piola and Rivas, 1997; Guerrero and Piola, 1997; Acha et al., 2004; Bogazzi et al., 2005; Romero et al., 2006; Carreto et al., 2007; Piola et al., 2010; Paparazzo et al., 2010; Rivas and Pisoni, 2010; Acha et al., 2015, Glembocki et al.,
2015 and other references therein) was considered (shown in Fig. 8; see also Supp. App. 1). On the other hand, a comparison with previous scarce results concerning bioerosion traces on molluscan shells from other areas of the Argentinian littoral (Richiano et al., 2012, 2015) is presented in Table 5. Records of six ichnogenera are reported for the first time for Golfo San Jorge: Caulostrepsis isp., Iramena isp., Podichnus isp., Pinaceocladichnus isp., Renichnus isp. and Umbichnus isp.

Among possible environmental factors influencing bioerosion activities in the study area, substrate nature, sedimentation rate and salinity are not dissimilar at one individual locality in comparison with the others. However, water circulation-nutrients-productivity (Carreto et al., 2007; Piola et al., 2010; Olguín-Salinas et al., 2015) seems to be the main controlling factor between areas and through time (Figs. 1, 8; Supp. App. 1). 


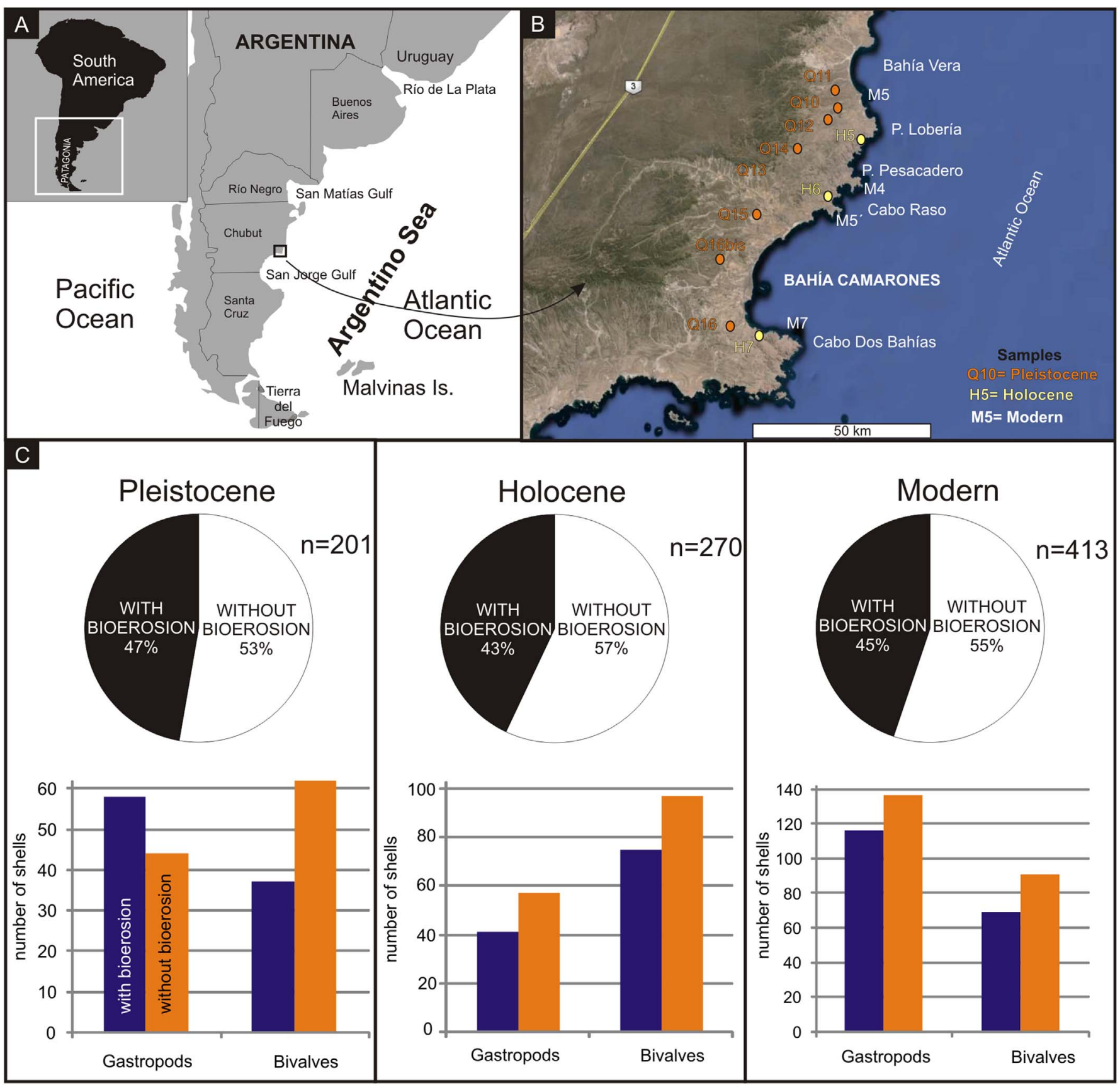

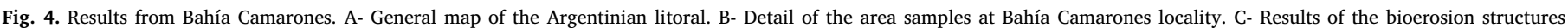
identified at Bahía Camarones locality.

It could have been expected that the ichnodiversity pattern (Figs. 4, 5; Tables 3,4 ) would match the benthic molluscan (gastropod and bivalve species) biodiversity pattern obtained previously for Patagonia, characterized by a southwards decreasing trend. This trend is mainly controlled by SST and, secondarily, by salinity gradients (Aguirre et al., 2011a). It is interesting to note that, by contrast, the modern ichnodiversity pattern of Golfo San Jorge is higher southwards, associated with modern enhanced productivity areas at coastal fronts (Fig. 8). Interestingly, the ichnodiversity trend matches with the southwards highest bryozoan species richness reported for the Argentine continental shelf (SWA) (López Gappa, 2000). As shown among others by Carreto et al. (2007), Romero et al. (2006), Paparazzo et al. (2010) and Glembocki et al. (2015), two areas within the Golfo San Jorge are characterized by high chlorophyll-a concentration linked to higher productivity levels (triggered by a complex interaction between SST, salinity, nutrients,
pH, circulation) (Fig. 8, E-F): the northern Golfo San Jorge (NGSJ) and southern Golfo San Jorge (SGSJ) coastal fronts (among others Acha et al., 2004; Bogazzi et al., 2005; Piola and Falabella, 2009; Acha et al., 2015; equivalent to the so-called northern closed area and Mazarredo closed area sensu Glembocki et al., 2015) (1 and 2, Fig. 8E). It is widely acknowledged that highest productivity zones are associated with coastal fronts (Piola and Falabella, 2009; Derisio et al., 2014; Acha et al., 2015).

In particular, Camarones area shows a similar ichnodiversity pattern as previously recorded for Argentina (Richiano et al., 2012, 2015). It is outstanding that although the percentage of bioeroded shells is similar across time, a minor ichnodiversity and bioerosion intensity characterize the Holocene in this area. Most interestingly, the Late Pleistocene is the only time slice which is characterized by higher bioeroded shells for gastropods, mostly of the dominant gastropod Tegula atra 


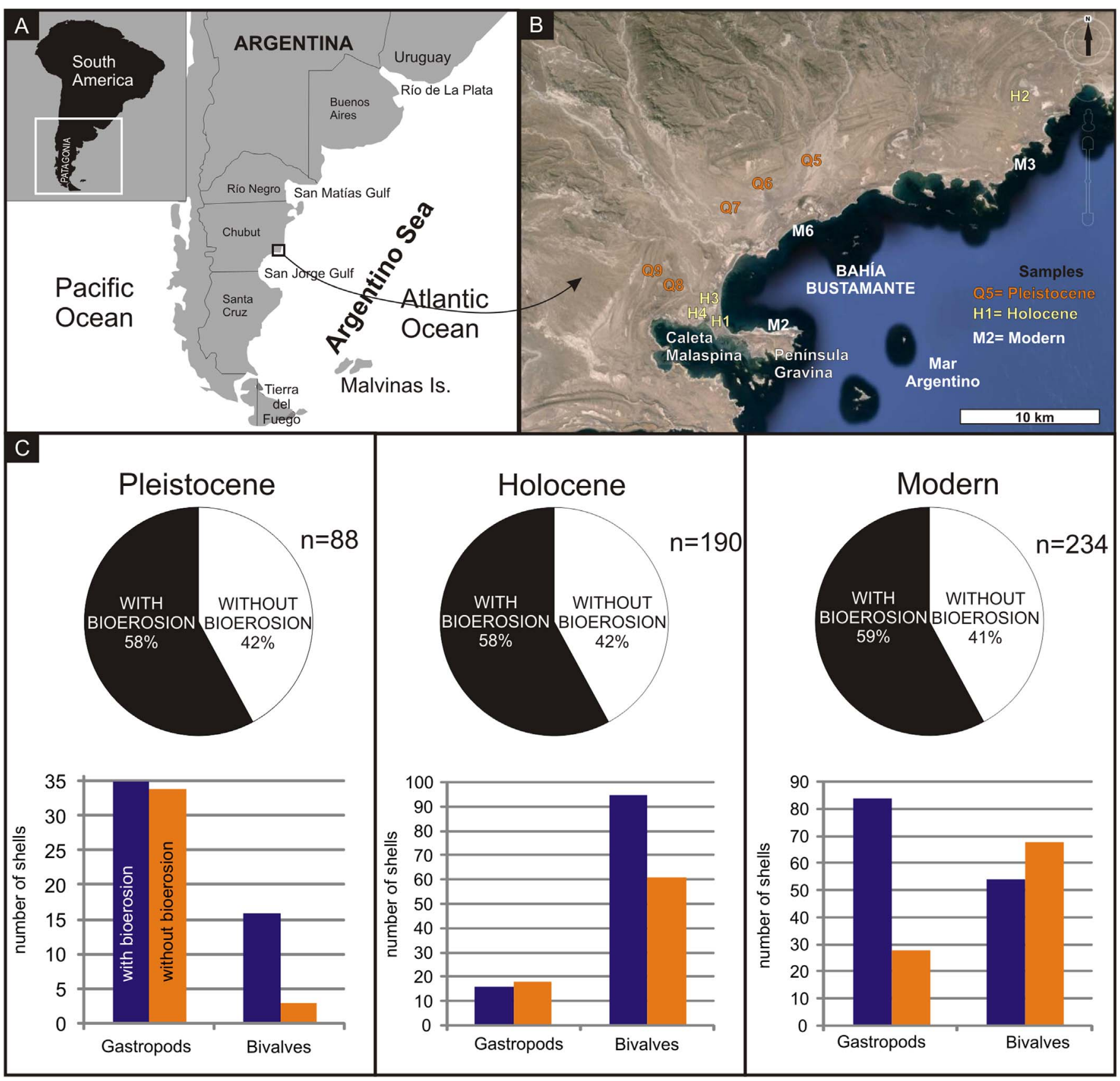

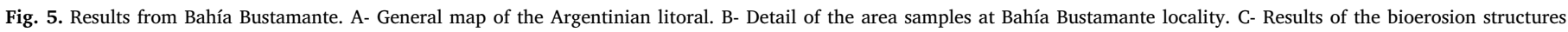
identified at Bahía Bustamante locality.

(cold water, typical of nutrient-rich water masses, epifaunal, and feeding mainly on fitoplankton and dispersed by macroalgae), a species which became extinct from the Mar Argentino in the Holocene (Table 3, Fig. 4). Overall, these differences can be associated with SST (colder for the Late Pleistocene, warmer for the mid-Holocene) and consequent changes in palaeocirculation-nutrient concentration. During the midHolocene the Brazil warm current (Fig. 8A) was more extensive and southwards displaced vs. a less intensified cold Malvinas/Falkland current (Aguirre et al., 2013; Richiano et al., 2015).

Bahía Bustamante locality, more influenced by the NGSJ coastal front, shows a major number of bioeroded shells and higher ichnodiversity (modern, fossil Holocene) than Camarones area. Moreover, the modern littoral area at Bustamante exhibits the highest ichnodiversity pattern for the whole Argentinean coastal area (Richiano et al., 2012, 2015) (Table 5). The most frequent ichnotaxa (Oichnus isp.,
Praedichnia, produced by carnivorous gastropods; Iramena isp., Domichnia, produced by cheilostome bryozoans dependant on nutrient-rich waters) are expected to be enhanced in highly productive oceanic waters at this area (e.g. Carreto et al., 2007; Olguín-Salinas et al., 2015; Cadier et al., 2017). In fact, abundant predation levels have been documented in more productive waters (Edinger, 2002). Also, it has recently been reported that top predators track frontal zones in the Southern Ocean (Koubbi et al., 2014). Specifically, the modern bryozoan biodiversity pattern (increasing towards higher latitudes along the Argentine shelf; López Gappa, 2000), is associated primarily to SST and to enhanced productivity (higher levels southwards in colder waters of high chlorophyll-a concentration) (Fig. 8, F). Overall, reinforcing a strong linkage between the ichnodiversity pattern and productivity-chlorophyll- $a$ distribution (Suppl. App. 1).

The Holocene dominance of Oichnus at Bustamante area (Figs. 6, 7) 


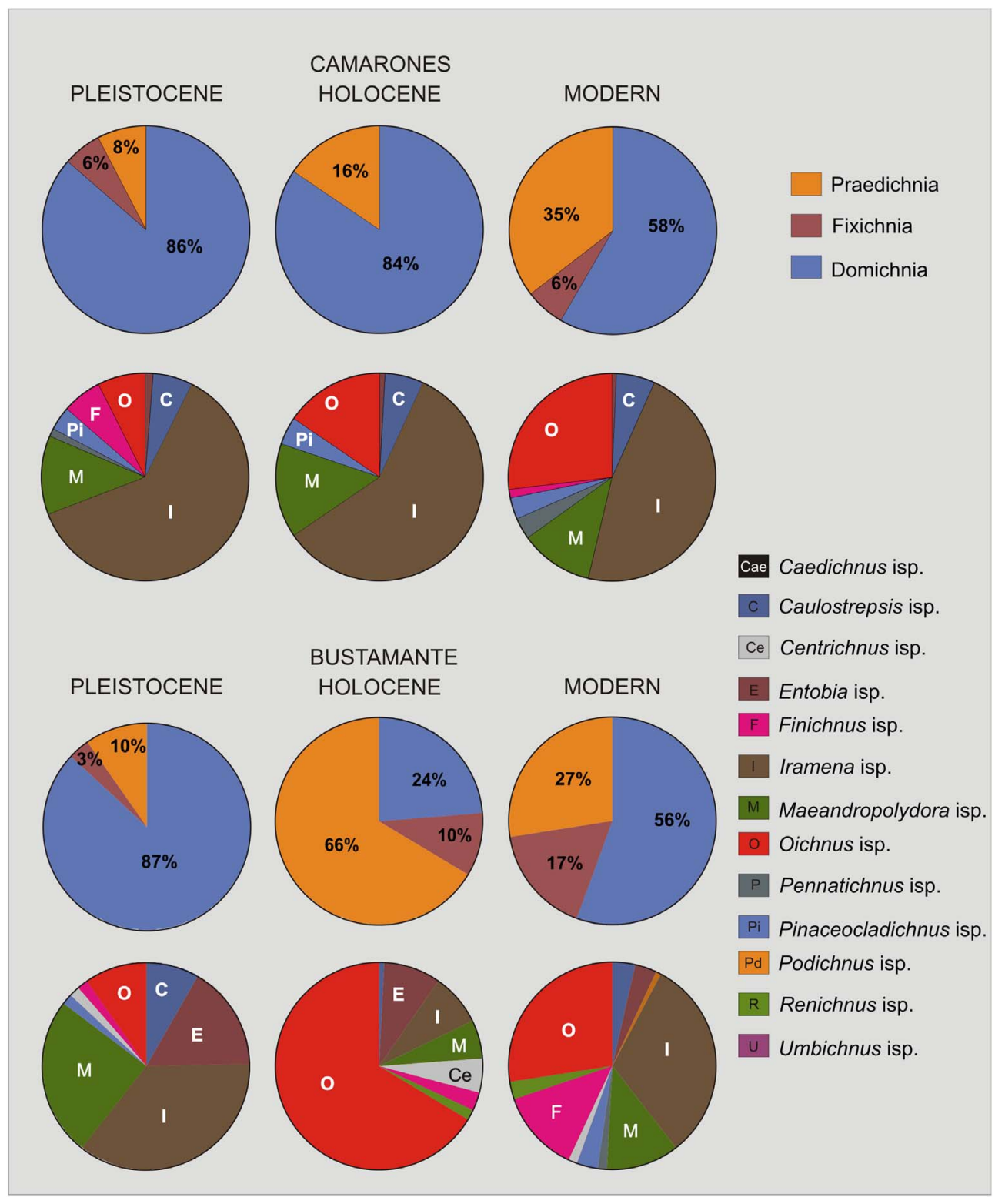

Fig. 6. Percentages of trace fossils according to ichnotaxa and to ethological categories in Camarones and Bustamante areas. For additional information about authors of ichnogenera (see Suppl. App. 2).

points to higher nutrients concentration during the Hypsithermal than at present. However, the Late Pleistocene highest abundance of bryozoan traces suggests that it was more enhanced - mainly during the Last Interglacial- than in the Holocene, with a more intensified northern Patagonia Front.

Apart from that, the distribution of traces made by Ctenostomata bryozoans at Bahía Bustamante area across time can be useful as a palaeoenvironmental tool. For example, these traces (Pinaceocladichnus, Pennatichnus) are all more frequent in modern and Late Pleistocene records; by contrast, scarcer or absent within the mid-Holocene. Pennatichnus isp. was not recorded in Holocene samples, adding evidence for a warmer oceanic scenario during the Hypsithermal. Warmer oceanic waters leading to acidification can be expected to have changed marine ecosystem composition and function and reduced phytoplankton/productivity levels (e.g., Pörtner, 2008; Porzio et al., 2011; Cornwall et al., 2012; Fauville et al., 2013; Kroeker et al., 2013; Wallace et al., 2014; Gruber, 2015; Prada et al., 2017; Wang et al., 2017, and other references therein).

This new evidence is in agreement with our previous interpretations based on molluscan palaeobiogeographical analyses. For the northern Argentinean littoral, molluscs suggested a higher SST during the mid-
Holocene, while for central Patagonia such evidence is revealed only by these trace fossils (Richiano et al., 2015). On top of that, a higher bioerosion intensity for the Late Pleistocene shells is an independent evidence for an oceanic setting of enhanced productivity (Edinger, 2002), thus in support of a colder littoral scenario of higher nutrient concentration during the late Pleistocene, especially the Last Interglacial (Suppl. App. 4).

On the contrary, the ichnodiversity identified previously for central and southern Golfo San Jorge and for southern Patagonia areas (Table 5) (Richiano et al., 2012, 2015) is considerably lower, most likely due to a different oceanographic regime: the central part of Golfo San Jorge does not match with coastal fronts whereas the southern part (Mazarredo-P.Deseado) coincides with the SGSJ coastal front but it is under the high influence of the low salinity Magellanic Plume (Fig. 8D; Suppl. App. 1) which flows inside the southern part of the gulf. It is known that salinity is one of the main strong controlling factors for ichnology patterns. Also, a permanent thermohaline front is located in the southern sector of Golfo San Jorge, while lower concentration of nutrients characterizes the central part of the gulf (Carreto et al., 2007). Along southern Patagonia the influence of the Magellan Plume is even stronger. 


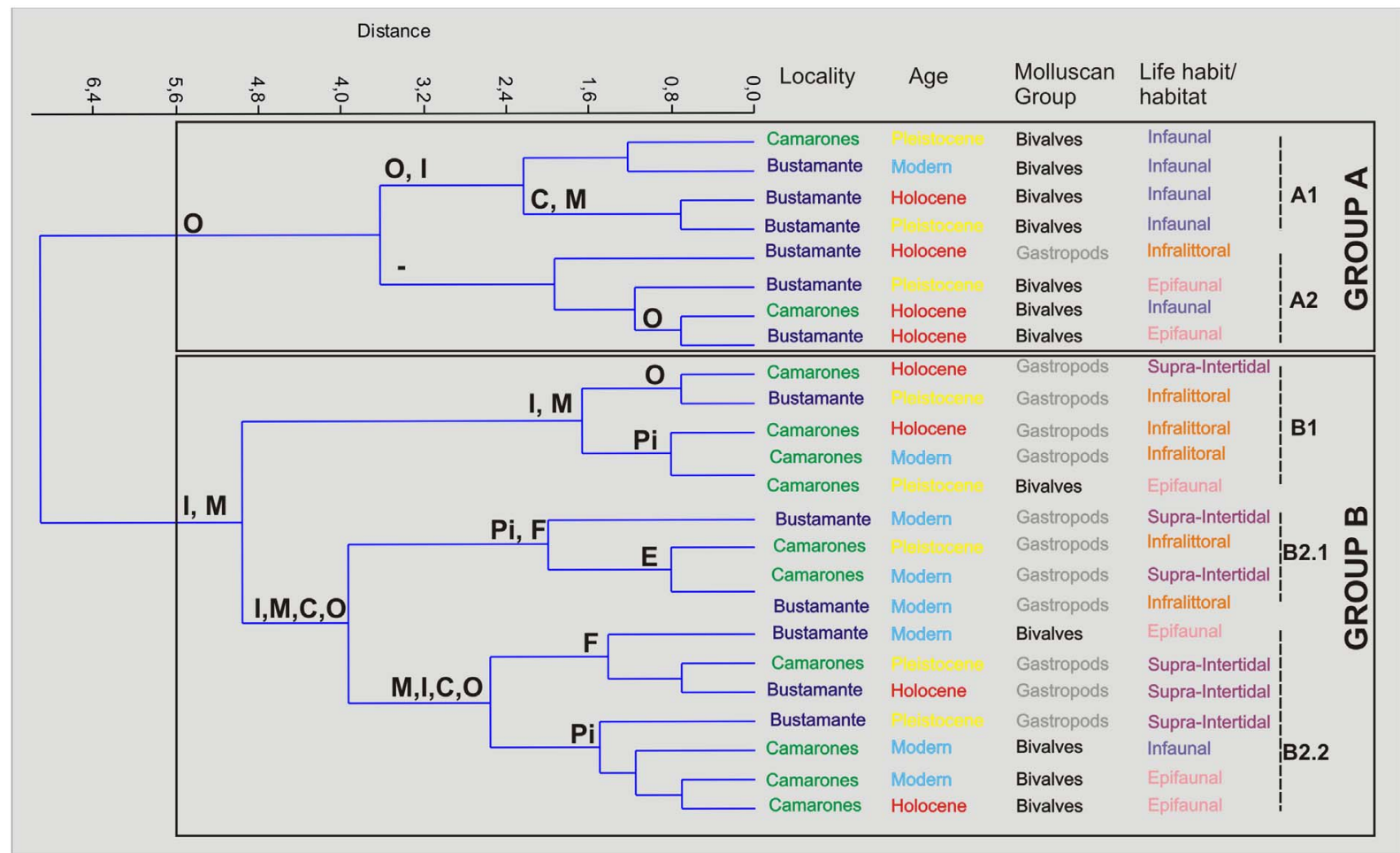

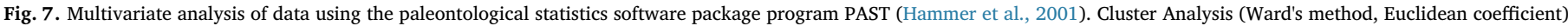

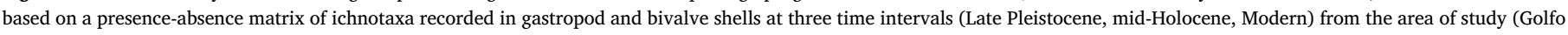

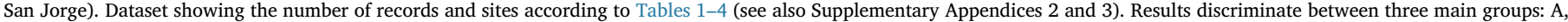

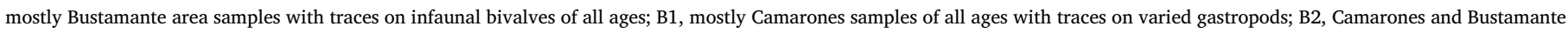

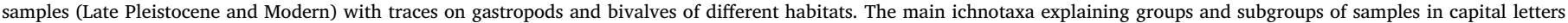
(abbreviations as in Fig.6 and Suppl. App. 2).

To sum up, based on this new evidence together with previous satellite imaging and geomorphological data (e.g., successive Late Pleistocene and Holocene beach ridge systems preserved along Golfo San Jorge since MIS5 points to the same general topography than present), we hypothesize that the oceanic front of NGSJ has been active at least since the Late Pleistocene, when it was more intensified than present. As pointed out by Piola and Falabella (2009), oceanic fronts are related to topographic features and are stable across time. Moreover, all of these differences between proximal zones (environmentally and/or oceanographically) support our idea of a strong linkage between bioerosion-productivity-circulation in the area of study.

This study represents the first approach to understand the bioerosion activity of different littoral organisms at Golfo San Jorge area (Central Patagonia), a clue geographic sector for palaeoclimatic interpretations. Large amounts of $\mathrm{CO}_{2}$ (carbon dioxide) are sequestered in the Patagonian sector of the Mar Argentino, thus particularly relevant for climate regulation within the context of the Southern Ocean (e.g., Piola and Falabella, 2009). Further studies need to focus on broadening the area of study to enlarge sampling and the significance of preliminary interpretations of trace fossils from Quaternary deposits of the Patagonian coastal area.

As Berger et al. (2010) clearly showed, to better understand the mechanisms underlying Quaternary oceans-climate change, more data from surface waters and from varied geographical areas worldwide are as yet still needed. Particularly, in relation with mechanisms controlling the export of carbon from surface waters in response to climate change, they also modify productivity levels -and consequently spot ichnotaxa. Menviel et al. (2015) pointed out that the linkage between atmospheric $\mathrm{CO}_{2}$ levels and ocean ventilation rates is not unequivocal and that largescale reorganizations of oceanic circulation have a strong impact on both nutrient utilization and climate. Further, more detailed Late Quaternary ichnological coastal datasets from Patagonia and the
Southwestern Atlantic can provide useful indirect evidence for such differences in climatically driven nutrient availability, linked to modern and past oceanographical dynamics.

\section{Conclusions}

The ichnological characterization (qualitatively/semiquantitatively) of northern Golfo San Jorge coastal area responds to different palaeoenvironmental/palaeoceanographical configurations since the Late Pleistocene. Among several possible environmental factors, the biological activities are determined mainly by temperature and nutrients-productivity. Local oceanographical dynamics explains minor differences between Bahía Bustamante and Bahía Camarones bioerosive patterns and, also, variations in the relative abundance of target ichnotaxa across time (e.g., Oichnus, Iramena, Pinaceocladichnus, Pennatichnus), which are associated with modern enhanced productivity levels at areas linked to coastal fronts.

1. The Late Pleistocene pattern leads to assume colder, more productive waters and a more intensified coastal front at northern San Jorge (NGSJ) area during the Last Interglacial, in comparison with the Holocene and present.

2. Bioerosion traces made by Ctenostomate bryozoans typical of cold waters can be used as indicators of highly productive waters.

3. Particularly, Pennatichnus, absent in the mid-Holocene, can be useful as a palaeoclimate tool in this area (warmer waters, Hypsithermal effect).

To sum up, our results reinforce different littoral scenarios for the Holocene (higher SST) vs. Late Pleistocene (colder SST) and modern time intervals at central Patagonia with consequences in palaeocirculation-productivity. Slightly higher SST for the Holocene were shown by 


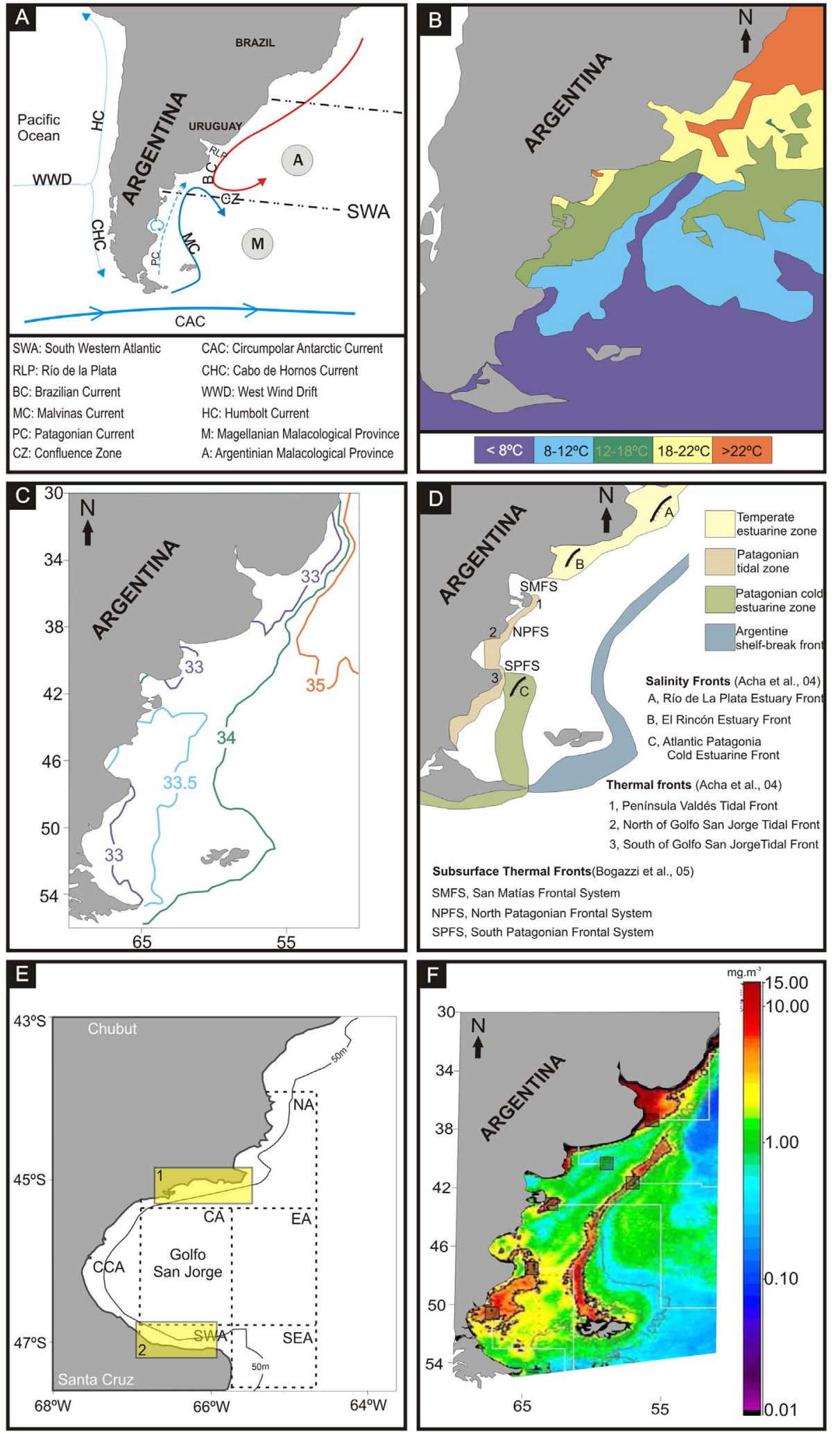

Fig. 8. Modern oceanographic condition of South Western Atlantic. Modified from Acha et al., 2004; Bogazzi et al., 2005; Romero et al., 2006; Romero, 2008; Glembocki et al., 2015. A- Currents and Malacological Provinces. B- Sea Surface Temperature (SST). C- Salinity curves (in grs/ltrs). D- Main oceanographical fronts in the Mar Argentino. EMain fronts in the Golfo san Jorge area. Particular closed areas of Golfo San Jorge; 1- Northern closed area, 2- Mazarredo closed area. F: Productivity (Average summer distribution of satellite Chlorophyll-a concentration in the Mar Argentino (1998-2004) (taken and modified from Carreto et al., 2007; Romero, 2008). molluscs for the northern Argentinean littoral, while for Patagonia, the molluscan taxonomic composition is practically uninformative; without the study of bioerosion, this scenario would not be evident. Finally, considering that coastal fronts depend on topographic features and are stable across time, we suggest that the GSJ has been an important oceanographic driver in Patagonia since at least the Last Interglacial (Late Pleistocene).

\section{Acknowledgements}

We thank Matías Soriano for allowing us access to his Bahía Bustamante geosite and logistical help and to M. Donato for his help with the statistics. This work was benefitted by grants from Agencia Nacional de Promoción Científica y Tecnológica (PICT 2006-468, PICT 2013-1298), CONICET (PIP 0080, PIP 0729 and PIP 0372), Universidad 
Table 5

Comparison of the bioerosion structures along the Quaternary marine deposits of Argentina.

(Data recovered and compiled from our previous studies, i.e., Farinati et al., 2006; Farinati, 2007; Richiano et al., 2012, 2015)

\begin{tabular}{|c|c|c|c|c|c|c|c|c|c|c|c|c|c|c|c|c|c|c|c|c|}
\hline \multirow{3}{*}{$\begin{array}{l}\text { Potencial } \\
\text { producers }\end{array}$} & & \multirow{3}{*}{ Ichnogenus } & \multirow{2}{*}{\multicolumn{3}{|c|}{$\begin{array}{c}\text { Buenos Aires } \\
\text { province }\end{array}$}} & \multirow{2}{*}{\multicolumn{3}{|c|}{ Northern Patagonia }} & \multicolumn{9}{|c|}{ GOLFO SAN JORGE } & \multirow{2}{*}{\multicolumn{3}{|c|}{$\begin{array}{l}\text { Southern } \\
\text { Patagonia }\end{array}$}} \\
\hline & & & & & & & & & \multicolumn{3}{|c|}{ Bahía Camarones } & \multicolumn{3}{|c|}{ Bahía Bustamante } & \multicolumn{3}{|c|}{ Central \& Southern } & & & \\
\hline & & & PL & $\mathrm{HOL}$ & MOD & $\mathrm{PL}$ & $\mathrm{HOL}$ & MOD & $\mathrm{PL}$ & $\mathrm{HOL}$ & MOD & $\mathrm{PL}$ & $\mathrm{HOL}$ & MOD & PL & $\mathrm{HOL}$ & MOD & PL & $\mathrm{HOL}$ & MOD \\
\hline Crabs & $\mathrm{Ca}$ & Caedichnus & & & & & & & & & & & & & & & & & & \\
\hline Annelids & c & Caulostrepsis & & & & & & & & & & & & & & & & & & \\
\hline Cirripeds & $\mathrm{Ce}$ & Centrichnus & & & & & & & & & & & & & & & & & & \\
\hline Porifers & $E$ & Entobia & & & & & & & & & & & & & & & & & & \\
\hline Cheilostomata & $F$ & Finichnus & & & & & & & & & & & & & & & & & & \\
\hline Ctenostomata & 1 & Iramena & & & & & & & & & & & & & & & & & & \\
\hline Annelids & $M$ & Maeandropolydora & & & & & & & & & & & & & & & & & & \\
\hline Gastropods & 0 & Oichnus & & & & & & & & & & & & & & & & & & \\
\hline Ctenostomata & $P$ & Pennatichnus & & & & & & & & & & & & & & & & & & \\
\hline Ctenostomata & $P i$ & Pinaceocladichnus & & & & & & & & & & & & & & & & & & \\
\hline Brachiopods & $P d$ & Podichnus & & & & & & & & & & & & & & & & & & \\
\hline Gastropods & $R$ & Renichnus & & & & & & & & & & & & & & & & & & \\
\hline Unknown? & $u$ & Umbichnus & & & & & & & & & & & & & & & & & & \\
\hline
\end{tabular}

Nacional de La Plata (PI N11/587 and N11/726) and Universidad Nacional del Sur (PGI 24/H123). To the editor A. Piola and to four anonymous reviewers whose critical comments highly improved the first version of this work.

\section{Appendix A. Supplementary data}

Supplementary data to this article can be found online at http://dx. doi.org/10.1016/j.jmarsys.2017.07.010.

\section{References}

Aberhan, M., Fürsich, F., 1991. Palaeoecology and palaeoenvironments of the Pleistocene deposits at Bahia la Choya (Gulf of California, Sonora, Mexico). Zitteliana 18, 135-163.

Acha, E., Mianzan, H., Guerrero, R., Favero, M., Bava, J., 2004. Marine fronts at the continental shelves of austral South America physical and ecological processes. J. Mar. Syst. 44, 83-105.

Acha, E.M., Mianzan, H.W., Guerrero, R.A., Carreto, J., Giberto, D.A., Montoya, N., Carignan, M., 2008. An overview of physical and ecological processes in the Río de la Plata Estuary. Cont. Shelf Res. 28, 1579-1588.

Acha, E.M., Piola, A., Iribarne, O., Mianzan, H., 2015. Ecological Processes at Marine Fronts: Oases in the Ocean. Springer Briefs in Environmental Science (ISBN: 978-3319-15478-7).

Aguirre, M., Negro Sirch, Y., Richiano, S., 2005. Late Quaternary molluscan assemblages from Bahía Bustamante coastal area (Patagonia, Argentina): palaeoecology and palaeoenvironments. J. S. Am. Earth Sci. 20, 13-32.

Aguirre, M.L., Richiano, S., Negro Sirch, Y., 2006. Palaeoenvironments and palaeocli mates of the Quaternary molluscan faunas from the coastal area of Bahía VeraCamarones (Chubut, Patagonia). Palaeogeogr. Palaeoclimatol. Palaeoecol. 229, 251-286.

Aguirre, M., Richiano, S., Negro Sirch, Y., 2007. Moluscos de terrazas marinas cuaternarias del área de Camarones, Patagonia. Mon. Soc. Hist. Nat. Balears, 14, 81-120. Palma de Mallorca. (ISBN 84-96376-13-3).

Aguirre, M.L., Hlebzesebitch, J., Dellatorre, F., 2008. Late Cenozoic invertebrate paleontology, with emphasis on mollusks. In: Rabassa, J. (Ed.), Late Cenozoic of Patagonia and Tierra del Fuego. Elsevier, pp. 285-325.

Aguirre, M., Richiano, S., Alvarez, M.F., Eastoe, C., 2009. Malacofauna Cuaternaria De Litoral Norte De Santa Cruz (Patagonia, Argentina). Geobios 42, 411-434.

Aguirre, M., Donato, M., Richiano, S., Farinati, E., 2011a. Pleistocene and Holocene in terglacial molluscan assemblages from Patagonian and Bonaerensian littoral (Argentina, SW Atlantic): palaeobiodiversity and palaeobiogeography. Palaeogeogr Palaeoclimatol. Palaeoecol. 308, 277-292.

Aguirre, M.L., Richiano, S., Farinati, E.A., Fucks, E., 2011b. Taphonomic comparison between two bivalves (Mactra and Brachidontes) from Late Quaternary deposits in northern Argentina: which kind of intrinsic and extrinsic factors prevail under different paleoenvironmental conditions? Quat. Int. 233, 113-129.

Aguirre, M.L., Richiano, S., Donato, M., Farinati, E.A., 2013. Tegula atra (Lesson, 1830) (Mollusca, Gastropoda) in the marine Quaternary of Patagonia (Argentina, SW Atlantic): biostratigraphical tool and paleoclimate-palaeoceanographical signal.
Quat. Int. 305, 163-187.

Aguirre, M.L., Richiano, S., Alvarez, A., Farinati, E.A., 2015. Reading shell shape: implications for palaeoenvironmental reconstructions. A case study for bivalves from the marine Quaternary of Argentina (South Western Atlantic). Hist. Biol. http://dx. doi.org/10.1080/08912963.2015.1026898.

Allmonn, W.D., Martin, R.E., 2014. Seafood through time revisited: the Phanerozoic increase in marine trophic resources and its macroevolutionary consequences. Paleobiology 40, 256-287.

Bastida, R., Urien, C., Lichtschein, V., Roux, A., Arias, P., 1981. Investigaciones sobre comunidades bentónicas. Características generales del sustrato (Campañas IV, V, X y XI B/I "Shinkai Maru"). vol. 83. Instituto Nacional de Investigación y Pesqueropp. 318-339.

Bastida, R., Roux, A., Martínez, E., 1992. Benthic communities of the Argentine continental shelf. Oceanol. Acta 15, 687-698.

Bastida, R., Zamponi, M., Bremec, C., Roux, A., Genzano, G., Elías, R., 2007. Las comunidades bentónicas. El Mar y sus recursos pesqueros. vol. 5. Instituto de Investigación y Desarrollo Pesqueropp. 91-126.

Bauch, H., 2013. Interglacial climates and the Atlantic meridional overturning circulation: is there an Arctic controversy? Quat. Sci. Rev. 63, 1-22.

Berger, W.H., Schulz, M., Wefer, G., 2010. Quaternary oceans and climate change: lessons for the future? Int. J. Earth Sci. 99, 171-189.

Bogazzi, E., Baldoni, A., Rivas, A., Martos, P., Reta, R., Orensanz, J., Lasta, M., Dell'arciprete, P., Werner, F., 2005. Spatial correspondence between areas of concentration of Patagonian scallop (Zygochlamys patagonica) and frontal systems in the southwestern Atlantic Fish. Oceanographica 14, 359-376.

Boltovskoy, D. (Ed.), 2007. Atlas de Sensibilidad Ambiental de la costa y el Mar Argentino, , atlas.ambiente.gov.ar.

Bromley, R.G., 1994. The palaeoecology of bioerosion. In: Donovan, S.K. (Ed.), The Paleobiology of Trace Fossils. John Wiley \& Sons, Chichester.

Bromley, R.G., 2004. A stratigraphy of marine bioerosion. In: McIlroy, D. (Ed.), The Application of Ichnology to Palaeoenvironmental and Stratigraphic Analysis. Geological Society of London Special Publication, vol. 228. pp. 455-479.

Buatois, L.A., Mangano, M.G., 2011. Ichnology: Organism-substrate Interactions in Space and Time. Cambridge University Press, Cambridge.

Cadier, M., Gorgues, T., Sourisseau, M., Edwards, C.A., Aumont, O., Marié, L., Memery, L. 2017. Assessing spatial and temporal variability of phytoplankton communities' composition in the Iroise Sea ecosystem (Brittany, France): a 3D modeling approach. Part 1: biophysical control over plankton functional types succession and distribution. J. Mar. Syst. 165, 47-68.

Carreto, J.I., Carignan, M.O., Montoya, N.G., Cucchi Colleoni, D.A., 2007. Ecología del fitoplancton en los sistemas frontales del mar argentino. In: Carreto, J.I., Bremec, C. (Eds.), El Mar Argentino y sus recursos Pesqueros, El ambiente Marino Tomo V. INIDEP, Mar del Plata.

Cionchi, J.L., 1988. Geomorfología de la Bahía Bustamante y zonas adyacentes. Rev. Asoc. Geol. Argent. 43, 51-62.

Clarke, K.R., 1993. Non-parametric Multivariate Analysis of Changes in Community Structure.

Codignotto, J.O., Marcomini, S.C., Santillana, S.N., 1988. Terrazas marinas entre Puerto Deseado y Bahía Bustamante, Santa Cruz, Chubut. Rev. Asoc. Geol. Argent. 43, 43-50.

Codignotto, J., Kokot, R., Marcomini, S., 1992. Neotectonism and sea-level changes in the zone of Argentina. J. Coast. Res. 8, 125-133.

Cornwall, C., Hepburn, C., Pritchard, D., Currie, K., McGraw, C., Hunter, K., Hurd, C., 2012. Carbon-use strategies in macroalgae: differential responses to lowered $\mathrm{pH}$ and 
implications for ocean acidification. J. Phycol. 48, 137-144.

Derisio, C., Alemany, D., Acha, E.M., Mianzan, H., 2014. Influence of a tidal front on zooplankton abundance, assemblages and life histories in Península Valdés, Argentina. J. Mar. Syst. 139, 475-482.

Dutton, A., Carlson, A.E., Long, A.J., Milne, G.A., Clark, P.U., DeConto, R., Horton, B.P., Rahmstorf, S., Raymo, M.E., 2015. Sea-level rise due to polar ice-sheet mass loss during past warm periods. Science 349, 153-164.

Edinger, E.N., 2002. Bioerosion. In: Briggs, D.E.G., Crowther, P. (Eds.), Paleobiology II. Blackwell, New York.

Edinger, E., Risk, M., 2007. Sponge borehole size as a relative measure of bioerosion and paleoproductivity. Lethaia 29, 275-286.

Farinati, E.A., 2007. Trace fossils in firm sediment and skeletal substrates, Miocene to Pliocene, Patagonia, Argentina. In: Bromley, R., Buatois, L.A., Mángano, M.G., Genise, J., Melchor, R. (Eds.), Sediment-organism Interactions: A Multifaceted Ichnology. SEPM Special Publication, vol. 88. pp. 279-285.

Farinati, E.A., Spagnuolo, J.O., Aliotta, S., 2006. Bioerosión en moluscos holocenos del estuario de Bahía Blanca, Argentina. Ameghiniana 43, 45-54.

Fauville, G., Saljo, R., Dupont, S., 2013. Impact of ocean acidification on marine ecosystems: educational challenges and innovations. Mar. Biol. 160, 1863-1874.

Fernández, M., Roux, A., Fernández, E., Caló, J., Marcos, A., Aldacur, H., 2003. Grain-size analysis of surficial sediments from Golfo San Jorge, Argentina. J. Mar. Biol. Assoc. U. K. 83, 1193-1197.

Fernández, M., Carreto, J.I., Mora, J., Roux, A., 2005. Physico-chemical characterization of the benthic environment of the golfo San Jorge, Argentina. J. Mar. Biol. Assoc. U. K. 85, 1317-1328.

Fernández, M., Cucchi Colleoni, D., Roux, A., Marcos, A., Fernández, E., 2007. Caracterización físico-química del sistema bentónico en el sector sur del Golfo San Jorge, Argentina. Rev. Biol. Mar. Oceanogr. 42, 177-192.

Fernández, M., Mora, J., Roux, A., Cucchi-Colleoni, A.D., Gasparoni, J.C., 2008. New contribution on spatial and seasonal variability of environmental conditions of the golfo San Jorge benthic system, Argentina. J. Mar. Biol. Assoc. U. K. 88, 227-236.

Feruglio, E., 1950. Descripción Geológica de la Patagonia. Dirección General de Y.P.F., Tomo 3, Buenos Aires.

Flessa, K.W., Kowalewski, M., 1994. Shell survival and time-averaging in nearshore and shelf environments: estimates from the radiocarbon literature. Lethaia 27, 153-165.

Fürsich, F., Flessa, K., 1987. Taphonomy of tidal flat molluscs in the Northern Gulf of California: paleoenvironmental analysis despite the perils of preservation. PALAIOS 2, 543-559.

Gruber, N., 2015. Carbon at the coastal interface. Nature 517, 148-149.

Guerrero, R.A., Piola, A.R., 1997. Masas de Agua en la Plataforma Continental. In: Boschi, E.E. (Ed.), El mar Argentino y sus recursos pesqueros Tomo 1. Vol. 998. INIDEP, pp. $107-118$.

Glembocki, N.G., Williams, G.N., Góngora, M.E., Gagliardini, D.A., Orensanz, J.M., 2015. Synoptic oceanography of San Jorge Gulf (Argentina): a template for Patagonian red shrimp (Pleoticus muelleri) spatial dynamics. J. Sea Res. 95, 22-35.

Goldring, R., Cadée, G., Pollard, J., 2007. Climatic control of marine trace fossil distribution. In: Miller IIIW. (Ed.), Trace Fossils Concepts, Problems, Prospects. Elsevier, Amsterdam, pp. 159-171.

Haq, B.U., Hardenbol, J., Vail, P.R., 1987. Chronology of the fluctuating sea levels since the Triassic. Science 235, 1156-1167.

Hammer, Ø., Harper, D.A.T., Ryan, P.D., 2001. PAST: paleontological statistics software package for education and data analysis. Palaeontol. Electron. 4 (1). http://palaeoelectronica.org/2001_1/past/issue1_01.htm (9 pp.).

Hoffmann, J., Núñez, M., Píccolo, M., 1997. Características climáticas del Océano Atlántico Sudoccidental. In: Boschi, E. (Ed.), El Mar Y Sus Recursos Pesqueros, Instituto Nacional de Investigación y Desarrollo Pesquero, pp. 163-193.

Huntley, J.W., Scarponi, D., 2015. Geographic variation of parasitic and predatory traces on mollusks in the northern Adriatic Sea, Italy: implications for the stratigraphic paleobiology of biotic interactions. Paleobiology 41, 134-153.

Kidwell, S.M., 2001. Preservation of species abundance in marine death assemblages Science 294, 1091-1094.

Kidwell, S.M., Fürsich, F., Aigner, T., 1986. Conceptual framework for the analysis and classification of fossil concentrations. PALAIOS 1, 228-238.

Koubbi, P., De Broyer, C., Griffiths, H.J., Raymond, B., d'Udekem d'Acoz, C., Van de Putte, A.P., Danis, B., David, B., Grant, S., Gutt, J., Held, C., Hosie, G., Huettmann, F., Post, A., Ropert-Coudert, Y., Stoddart, M., Swadling, K.M., Wadley, V., De Broyer, C., Koubbi, P., Griffiths, H.J., Raymond, B., Udekem d'Acoz C.d', et al., 2014. Present and future of southern ocean biogeography. In: Biogeographic Atlas of the Southern Ocean. Scientific Committee on Antarctic Research, Cambridge, pp. 470-475.

Kroeker, K., Kordas, R., Crim, R., Hendriks, I., Ramajo, L., Singh, G., Duartes, C., Gattuso, J., 2013. Impacts of ocean acidification on marine organisms: quantifying sensitivities and interaction with warming. Glob. Chang. Biol. 19, 1884-1896.

Liow, L.-H., Di Martino, E., Voje, K.L., Rust, S., Taylor, P.D., 2016. Interspecific interactions through 2 million years: are competitive outcomes predictable? Proc. R. Soc. B Biol. Sci. http://dx.doi.org/10.1098/rspb.2016.0981.

Lisiecki, L.E., Raymo, M.E., 2005. A Pliocene-Pleistocene stack of 57 globally distributed benthic d180 records. Paleoceanography 20, 1-17.

López Gappa, J., 2000. Species richness of marine Bryozoa in the continental shelf and slope off Argentina (south-west Atlantic). Divers. Distrib. 6, 15-27.

Margalef, R., 1982. Ecología. Omega Ed., Barcelona. (951 pp.).

Meldahl, K., 2001. Shell taphonomy. In: Briggs, D.E.G., Crowther, P.R. (Eds.), Palaeobiology II. Blackwell Science, pp. 262-264.

Menviel, L., Spence, P., Golledge, N., England, M.H., 2015. Southern ocean overturning role in modulating high southern latitude climate and atmospheric $\mathrm{CO}_{2}$ on millennial timescales. Nova Acta Leopold. 408, 159-166.

Noble, R.S., Curran, H.A., Wilson, M.A., 1995. Paleoenvironmental and paleoecological analyses of a Pleistocene mollusc-rich lagoonal facies, San Salvador Island, Bahamas. Geol. Soc. Am. Spec. Pap. 300, 91-103.

Olguín-Salinas, H.F., Brandini, F., Boltovskoy, D., 2015. Latitudinal patterns and interannual variations of spring phytoplankton in relation to hydrographic conditions of the southwestern Atlantic Ocean $\left(34^{\circ}-62^{\circ}\right.$ S). Helgol. Mar. Res. 69, 177-192.

Palma, E., Matano, R., Piola, A., 2004. A numerical study of the Southwestern Atlantic Shelf circulation: barotropic response to tidal and wind forcing. J. Geophys. Res. 109, $1-17$.

Palma, E., Matano, R., Piola, A., 2008. A numerical study of the Southwestern Atlantic Shelf circulation: stratified ocean response to local and offshore forcing. J. Geophys. Res. 113, C11010. http://dx.doi.org/10.1029/2007JC004720.

Paparazzo, F., Bianucci, L., Schloss, I., Almandoz, G., Solís, M., Esteves, J., 2010. Crossfrontal distribution of inorganic nutrients and chlorophyll-a on the Patagonian Continental Shelf of Argentina during summer and fall. Rev. Biol. Mar. Oceanogr. 45, 107-119.

Parker, G., Paterlini, M., Violante, R., 1997. El fondo marino. In: Boschi, E.E. (Ed.), El mar argentino y sus recursos pesqueros. Instituto Nacional de Investigación y Desarrollo Pesquero, pp. 65-88.

Pierini, J.O., Lovallo, M., Gómez, E.A., Telesca, L., 2016. Fisher-Shannon analysis of the time variability of remotely sensed sea surface temperature at the Brazil-Malvinas Confluence. Oceanologia 58, 187-195.

Piola, A., Rivas, A., 1997. Corrientes en la plataforma continental. El Mar Argentino y sus recursos pesqueros. 1. Publicación del Instituto Nacional de Investigación y Desarrollo Pesquero (Mar del Plata)pp. 119-132.

Piola, A.R., Falabella, V., 2009. El mar Patagónico. In: Falabella, V., Campagna, C., Croxall, J. (Eds.), Atlas del Mar Patagónico. Especies y espacios Wildlife Conservation Society and BirdLife International, Buenos Aires, pp. 54-76.

Piola, A., Martínez Avellaneda, N., Guerrero, R., Jardón, F., Palma, E., Romero, S., 2010. Malvinas slope water intrusions on the northern Patagonia continental shelf. Ocean Sci. 6, 345-359.

Podestá, G.P., 1997. Utilización de datos satelitarios en investigaciones oceanográficas y pesqueras en el océano Atlántico Sudoccidental. In: Boschi, E. (Ed.), El Mar Argentino y sus recursos pesqueros, Tomo 1: Antecedentes históricos de las exploraciones en el mar y las características ambientales. Instituto Nacional de Investigación y Desarrollo Pesquero, Mar del Plata, pp. 195-222.

Pörtner, H., 2008. Ecosystem effects of ocean acidification in times of ocean warming: a physiologist's view. Mar. Ecol. Prog. Ser. 373, 203-217.

Porzio, L., Buia, M., Hall-Spencer, J., 2011. Effects of ocean acidification on macroalgal communities. J. Exp. Mar. Biol. Ecol. 400, 278-287.

Prada, F., Caroselli, E., Mengoli, S., Brizi, L., Fantazzini, P., Capaccioni, B., Pasquini, L., Fabricius, K.E., Dubinsky, Z., Falini, G., Goffredo, S., 2017. Ocean warming and acidification synergistically increase coral mortality. Sci Rep 7, 40842.

Ribolini, A., Aguirre, M., Baneschi, I., Consoloni, I., 2011. Holocene beach ridges and coastal evolution in the Cabo Raso Bay (Atlantic Patagonian Coast, Argentina). J. Coast. Res. 27, 973-983.

Richiano, S., Aguirre, M., Farinati, E., 2012. Bioerosion structures in Quaternary marine mollusks from Argentina. In: Netto, R., Carmona, N., Tognoli, F. (Eds.), Ichnology of Latin America. Sociedad Brasileira de Paleontologia, Monografias, vol. 2. pp. 159-177.

Richiano, S., Aguirre, M., Farinati, E., Davies, K., Castellanos, I., 2015. Bioerosion structures in Crepidula (Mollusca, Gastropoda) as indicators of latitudinal palaeoenvironmental changes: example from the marine Quaternary of Argentina. Palaeogeogr. Palaeoclimatol. Palaeoecol. 439, 63-78.

Rivas, A.L., Pisoni, J.P., 2010. Identification, characteristics and seasonal evolution of surface thermal fronts in the Argentinean Continental Shelf. J. Mar. Syst. 79, 134-143.

Rohling, E.J., 2013. Oxygen isotope composition of seawater. In: Elias, S.A. (Ed.), The Encyclopedia of Quaternary Science. vol. 2. Elsevier, Amsterdam, pp. 915-922.

Romero, S., 2008. Estimaciones satelitales de clorofila y los frentes oceánicos del Atlántico sudoccidental. (PhD thesis unpublish) Buenos Aires University (211 pp.).

Romero, S., Piola, A., Charo, M., Garcia, C., 2006. Chlorophylla variability off Patagonia based on SeaWiFS data. J. Geophys. Res. 111, 5-21.

Roux, A., Bastida, R., Bremec, C., 1993. Comunidades bentónicas de la Plataforma Continental Argentina. Campañas Transección BIP "Oca Balda” 1987/88/89. 41. Boletim Instituto Oceanografico Universdidade do Sao Paulopp. 81-94.

Ruiz-Etcheverry, L.A., Saraceno, M., Piola, A.R., Strub, P.T., 2016. Sea level anomaly on the Patagonian continental shelf: trends, annual patterns and geostrophic flows. J. Geophys. Res. Oceans. http://dx.doi.org/10.1002/2015JC011265.

Rutter, N., Schnack, E., del Río, L., Fasano, J., Isla, F., Radtke, U., 1989. Correlation and dating of Quaternary littoral zones along the Patagonian coast, Argentina. Quat. Sci. Rev. 8, 213-234.

Rutter, N., Radtke, U., Schnack, E., 1990. Comparison of ESR and amino acid data in correlating and dating Quaternary shorelines along the Patagonian coast, Argentina. J. Coast. Res. 6, 391-411.

Santos, A., Mayoral, E., Johnson, M.E., Gudveig Baarli, B., Cachao, M., da Silva, C.M., Ledezma-Vázquez, J., 2012. Extreme habitat adaptation by boring bivalves on vol canically active paleoshores from North Atlantic Macaronesia. Facies 58, 325-338.

Seilacher, A., 2007. Trace Fossil Analysis. Springer, Berlin.

Schellmann, G., 2007. Holozäne Meeresspiegelveränderungen - ESR Datierungen aragonitischer Muschelschalen-Paläotsunamis. vol. 199. Institut für Geographie an der Universität Bamberg im Selbstverlagpp. 983-996.

Schellmann, G., Radtke, U., 2010. Timing and magnitude of Holocene sea-level changes along the middle and south Patagonian Atlantic coast derived from beach ridge systems, littoral terraces and valley-mouth terraces. Earth Sci. Rev. 103, 1-30.

Spratt, R.M., Lisiecki, L.E., 2016. A Late Pleistocene sea level stack. Clim. Past 12, 1079-1092. http://dx.doi.org/10.5194/cp-12-1079-2016. 
Taylor, P.D., Wilson, M.A., 2003. Palaeoecology and evolution of marine hard susbtrate communities. Earth Sci. Rev. 62, 1-103.

Uchman, A., Demircan, H., Derman, A.S., Sevim, S., Szulc, J., Toker, V., 2002. Relative sea-level changes recorded in borings from a Miocene rocky shore of the Mut Basin, southern Turkey. Ann. Soc. Geol. Pol. 72, 263-270.

Wallace, R.B., Baumann, H., Grear, J.S., Aller, R.C., Gobler, C.J., 2014. Coastal ocean acidification: the other eutrophication problem. Estuar. Coast. Shelf Sci. 148, 1-13.

Walker, S., 2007. Traces of gastropod predation on molluscan prey in tropical reef environments. In: Miller IIIW. (Ed.), Trace Fossils Concepts. Problems Prospects. Elsevier, Amsterdam, pp. 159-171.

Wang, J., Dong, Y., Ding, M., Russell, B., 2017. Ocean acidification increases the sensitivity and variability of physiological responses of an intertidal limpet to thermal stress. Biogeosci. Discuss. http://dx.doi.org/10.5194/bg-2017-47.

Wilson, M.A., 2007. Macroborings and the evolution of marine bioerosion. In: Miller IIIW.
(Ed.), Trace Fossils Concepts, Problems, Prospects. Elsevier, Amsterdam, pp. 159-171.

Wilson, M.A., Curran, H.A., White, B., 1998. Paleontological evidence of a brief global sea-level event during the last interglacial. Lethaia 31, 241-250.

Wisshak, M., Tribollet, A., Golubic, S., Jakobsen, J., Freiwald, A., 2011. Temperate bioerosion: ichnodiversity and biodiversity from intertidal to bathyal depths (Azores). Geobiology 9, 492-520.

Yin, Q., Berger, A., 2015. Interglacial analogues of the Holocene and its natural near future. Quat. Sci. Rev. 120, 28-46.

Zachos, J., Pagani, M., Sloan, L., Thomas, E., Billupps, K., 2001. Trends, rhytms, and aberrations in global climate $65 \mathrm{Ma}$ to present. Science 292, 686-693.

Ziegler, B., 1983. Introduction to Palaeobiology: General Palaeontology. University of California, Ellis Horwood (225 p.). 